Article

\title{
A Comparative Study of the Catalytic Behaviour of Alkoxy-1,3,5-Triazapentadiene Copper(II) Complexes in Cyclohexane Oxidation
}

\author{
Oksana V. Nesterova (D), Maximilian N. Kopylovich (D) and Dmytro S. Nesterov *(D) \\ Centro de Química Estrutural, Instituto Superior Técnico, Universidade de Lisboa, Av. Rovisco Pais, \\ 1049-001 Lisboa, Portugal \\ * Correspondence: dmytro.nesterov@tecnico.ulisboa.pt
}

Received: 31 May 2019; Accepted: 26 June 2019; Published: 29 June 2019

\begin{abstract}
The mononuclear copper complexes $\left[\mathrm{Cu}\{\mathrm{NH}=\mathrm{C}(\mathrm{OR}) \mathrm{NC}(\mathrm{OR})=\mathrm{NH}\}_{2}\right]$ with alkoxy-1,3,5triazapentadiene ligands that have different substituents $\left(\mathrm{R}=\mathrm{Me}(\mathbf{1}), \mathrm{Et}(2),{ }^{n} \operatorname{Pr}(3),{ }^{i} \operatorname{Pr}(4)\right.$, $\mathrm{CH}_{2} \mathrm{CH}_{2} \mathrm{OCH}_{3}$ (5)) were prepared, characterized (including the single crystal X-ray analysis of 3) and studied as catalysts in the mild oxidation of alkanes with $\mathrm{H}_{2} \mathrm{O}_{2}$ as an oxidant, pyridine as a promoting agent and cyclohexane as a main model substrate. The complex 4 showed the highest activity with a yield of products up to $18.5 \%$ and turnover frequency (TOF) up to $41 \mathrm{~h}^{-1}$. Cyclohexyl hydroperoxide was the main reaction product in all cases. Selectivity parameters in the oxidation of substituted cyclohexanes and adamantane disclosed a dominant free radical reaction mechanism with hydroxyl radicals as $\mathrm{C}-\mathrm{H}$-attacking species. The main overoxidation product was 6-hydroxyhexanoic acid, suggesting the presence of a secondary reaction mechanism of a different type. All complexes undergo gradual alteration of their structures in acetonitrile solutions to produce catalytically-active intermediates, as evidenced by UV/Vis spectroscopy and kinetic studies. Complex 4, having tertiary $\mathrm{C}-\mathrm{H}$ bonds in its ${ }^{i} \mathrm{Pr}$ substituents, showed the fastest alteration rate, which can be significantly suppressed by using the $\mathrm{CD}_{3} \mathrm{CN}$ solvent instead of $\mathrm{CH}_{3} \mathrm{CN}$ one. The observed process was associated to an autocatalytic oxidation of the alkoxy-1,3,5-triazapentadiene ligand. The deuterated complex 4- $\mathrm{d}_{32}$ was prepared and showed higher stability under the same conditions. The complexes 1 and 4 showed different reactivity in the formation of $\mathrm{H}_{2}{ }^{18} \mathrm{O}$ from ${ }^{18} \mathrm{O}_{2}$ in acetonitrile solutions.
\end{abstract}

Keywords: copper alkoxy-1,3,5-triazapentadiene complexes; alkane functionalization; protection by deuteration; ${ }^{18} \mathrm{O}$ isotopic labelling

\section{Introduction}

Selective transformation of inactive $\mathrm{C}-\mathrm{H}$ bonds into functional groups is a challenging class of reactions with great potential for fine organic synthesis, late stage drug functionalization and other fields [1-5]. Due to the high inertness of $\mathrm{C}-\mathrm{H}$ bonds, especially sp ${ }^{3}$ ones, their activation often requires harsh conditions and/or strong oxidizing agents [6]. The stability of coordination compounds (catalysts) under the catalytic conditions is a critical parameter for achieving high efficiency of the catalytic system [7]. In the case of alkane functionalization, $\mathrm{C}-\mathrm{H}$-attacking species may be active enough to react with a catalyst causing its degradation and limiting the turnover numbers (TONs). Nature found a solution to this problem by continuous regeneration of the catalysts (enzymes). However, such an approach could be hardly implemented in the artificial catalytic systems, thus leaving the preparation of stable and robust catalysts as an obvious alternative.

One of the principal approaches is the use of all-inorganic compounds with no organic ligands and no groups that can be easily oxidized [8-11]. However, in most cases, the use of organic ligand is 
unavoidable as it is required for the creation of a certain coordination environment around the metal centre and stabilization of the reactive intermediates. For instance, selective oxidation of $\mathrm{C}-\mathrm{H}$ bonds with $\mathrm{Fe}^{\mathrm{IV} / \mathrm{V}}=\mathrm{O}$ high-valent metal-oxo $(\mathrm{HVMO})$ species requires a special geometry around the metal centre [12,13]. The ligands (typically polydentate $\mathrm{N}$-donor ones) should provide free cis-cites favouring the coordination of the oxidant and stabilization of HVMO intermediates [14]. Also, ligands must show pronounced stability towards oxidation $[13,14]$. If some groups within the ligand structure compete with a substrate, this could become a limiting factor towards reaching high TON values. For example, earlier we described the heterometallic complex $\left[\mathrm{Co}_{4} \mathrm{Fe}_{2} \mathrm{O}(\mathrm{L})_{8}\right]\left(\mathrm{H}_{2} \mathrm{~L}=\right.$ salicylidene-2-ethanolamine) which showed an impressive turnover number of $3.6 \times 10^{3}$ and turnover frequency of $1.1 \times 10^{4} \mathrm{~h}^{-1}$ in the oxidation of cyclohexane with hydrogen peroxide, but underwent rapid degradation of its Schiff base ligand under the catalytic conditions [15].

The 1,3,5-triazapentadienes ligands are N-donor isoelectronic analogues of $\beta$-diketones [16]. In contrast to rich catalytic chemistry of diketone complexes $[17,18]$, the catalytic features of triazapentadiene complexes are much less explored. Some transition metal complexes of triazapentadienes were applied as catalysts for oxidation of alcohols with air or peroxides and for Henry reaction [19-22]. The complexes of copper with 2,4-alkoxy-1,3,5-triazapentadienato ligand having various substituents demonstrated a pronounced stability under the conditions of oxidative catalysis, particularly towards the attack of ${ }^{t} \mathrm{BuO} \cdot$ radical [23]. The knowledge about the $\mathrm{C}-\mathrm{H}$ activation catalytic properties of triazapentadiene complexes is limited, although the 1,3,5-triazapentadiene moiety allows bidentate $\mathrm{N}_{2}$-donor coordination resembling many catalytically recognized ligands used for selective $\mathrm{C}-\mathrm{H}$ functionalization [13]. This contrasts with the recognized catalytic activity of copper complexes in various $\mathrm{C}-\mathrm{H}$ functionalization reactions [6,24-26], including alkane oxidation [27,28], amidation [29,30] and related processes [31-33]. In pursuit of our interest in alkane oxidation, we prepared the complexes $\left[\mathrm{Cu}^{\mathrm{II}}\{\mathrm{NH}=\mathrm{C}(\mathrm{OR}) \mathrm{NC}(\mathrm{OR})=\mathrm{NH}\}_{2}\right]\left(\mathrm{R}=\mathrm{Me}(\mathbf{1}), \mathrm{Et}(\mathbf{2}),{ }^{n} \operatorname{Pr}(\mathbf{3}),{ }^{i} \operatorname{Pr}(4)\right.$, $\left.\mathrm{CH}_{2} \mathrm{CH}_{2} \mathrm{OCH}_{3}(5)\right)$ and investigated their catalytic activity in mild cyclohexane oxidation using $\mathrm{H}_{2} \mathrm{O}_{2}$ as a terminal oxidant and pyridine as a promoter. Hydrogen peroxide is a cheap and environmentally friendly oxidant broadly used in fine chemistry as well as industry [34,35]. It is widely applied in the metal-catalysed $\mathrm{C}-\mathrm{H}$ bonds activation reactions $[6,24,36,37]$ due to its high efficiency and highest atom economy among the peroxides family. However, $\mathrm{H}_{2} \mathrm{O}_{2}$ is prone to forming highly reactive radical species, such as $\mathrm{HO}$ - radicals [6], which may easily attack the catalyst causing its degradation. Therefore, we investigated the stability of the complexes under the catalytic conditions for better understanding of the influence of the substituent $R$ of the ligand on the stability of the catalysts and their catalytic activity.

\section{Results}

\subsection{Synthesis of the Complexes}

The copper complexes $\left[\mathrm{Cu}^{\mathrm{II}}\{\mathrm{NH}=\mathrm{C}(\mathrm{OR}) \mathrm{NC}(\mathrm{OR})=\mathrm{NH}\}_{2}\right]\left(\mathrm{R}=\mathrm{Me}(\mathbf{1}), \mathrm{Et}(\mathbf{2}),{ }^{n} \operatorname{Pr}(\mathbf{3}),{ }^{i} \operatorname{Pr}(4)\right.$, $\left.\mathrm{CH}_{2} \mathrm{CH}_{2} \mathrm{OCH}_{3}(5)\right)$ were synthesized as described earlier [23] by mixing copper acetate with sodium dicyanamide in alcohol $(\mathrm{ROH})$ at reflux and heating for approximately $12 \mathrm{~h}$ (Scheme 1 ). The reaction proceeds via the formation of dicyanamide copper complexes as intermediates [23]. The reaction utilizes cheap and readily-available reagents and affords the complexes 1-5 in high yield. All the compounds are soluble in the reaction solvents (alcohols) as well as in acetonitrile. The authenticity of the obtained complexes 1, 2, 4 and 5 was confirmed by comparison of their elemental analyses with the reference data [23], while compound 3, for the first time, was characterized by single X-ray analysis. 
<smiles>[R]OC1=NC([R])=NC2(N=C([R])N=C([R])N2)N1</smiles>

1: $\mathrm{R}=\mathrm{Me} \quad$ 3: $\mathrm{R}={ }^{n} \mathrm{Pr}$

2: $\mathrm{R}=\mathrm{Et} \quad$ 4: $\mathrm{R}={ }^{\mathrm{P}} \mathrm{Pr}$

5: $\mathrm{R}=\mathrm{CH}_{2} \mathrm{CH}_{2} \mathrm{OMe}$

Scheme 1. Synthesis of complexes 1-5.

\subsection{Crystal Structure of 3}

The single crystal X-ray analysis reveals three features of the mononuclear structure where the $\mathrm{Cu}(\mathrm{II})$ atom is in a distorted square-planar coordination environment with two monoanionic 1,3,5-triazapentadienato species acting as $N, N$-chelators and forming two six-membered $\mathrm{Cu}$ metallacycles (Figure 1). The $\mathrm{Cu}-\mathrm{N}$ bond distances are almost equal (from 1.929(5) to 1.935(5) $\AA$ ) and the cis $\mathrm{N}-\mathrm{Cu}-\mathrm{N}$ angles are close to $90^{\circ}$ varying from $87.8(2)^{\circ}$ to $96.0(2)^{\circ}$ (Table 1 ). In contrast to the structures of complexes 1, 2, 4 and 5 [23], the $\mathrm{N}_{4}$ environment around the copper atom is not completely planar with two ligands rotated at $24.2^{\circ}$ to each other.

The complex molecules are joined together by a set of $\mathrm{N}-\mathrm{H} \cdots \mathrm{O}$ and $\mathrm{N}-\mathrm{H} \cdots \mathrm{N}$ hydrogen bonds, involving the nitrogen atoms from $\mathrm{C}=\mathrm{NH}$ imine groups and the $n$-propoxy oxygen atoms of the

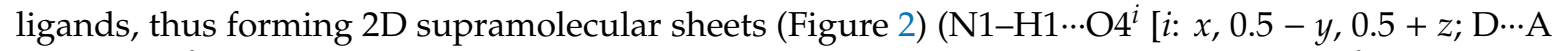
$\left.=3.588(6) \AA, \mathrm{D}-\mathrm{H} \cdots \mathrm{A}=118(4)^{\circ}\right], \mathrm{N} 6-\mathrm{H} 6 \cdots \mathrm{O} 1^{i i}[i i: x, 0.5-y,-0.5+z ; \mathrm{D} \cdots \mathrm{A}=3.511(7) \AA, \mathrm{D}-\mathrm{H} \cdots \mathrm{A}=$ $\left.164(5)^{\circ}\right], \mathrm{N} 3-\mathrm{H} 3 \cdots \mathrm{N} 5^{i i i}\left[\right.$ [iii: $\left.x, 1.5-y, 0.5+z ; \mathrm{D} \cdots \mathrm{A}=3.764(6) \AA{ }^{\circ}, \mathrm{D}-\mathrm{H} \cdots \mathrm{A}=150(4)^{\circ}\right]$ and $\mathrm{N} 4-\mathrm{H} 4 \cdots \mathrm{N}^{i v}$ [iv: $\left.\left.x, 1.5-y, 0.5+z ; \mathrm{D} \cdots \mathrm{A}=3.516(7) \AA, \mathrm{D}-\mathrm{H} \cdots \mathrm{A}=157(5)^{\circ}\right]\right)$. The location of the protruding $n$-propoxy groups of the 1,3,5-triazapentadienato ligands into the intersheet space prevents the increasing of the dimensionality of the H-bonded polymer to an infinite three-dimensional framework and keeps the supramolecular layers apart (Figure 3). The shortest $\mathrm{Cu} \cdots \mathrm{Cu}$ separation within the 2D polymeric sheet is 6.1598(9) $\AA$.

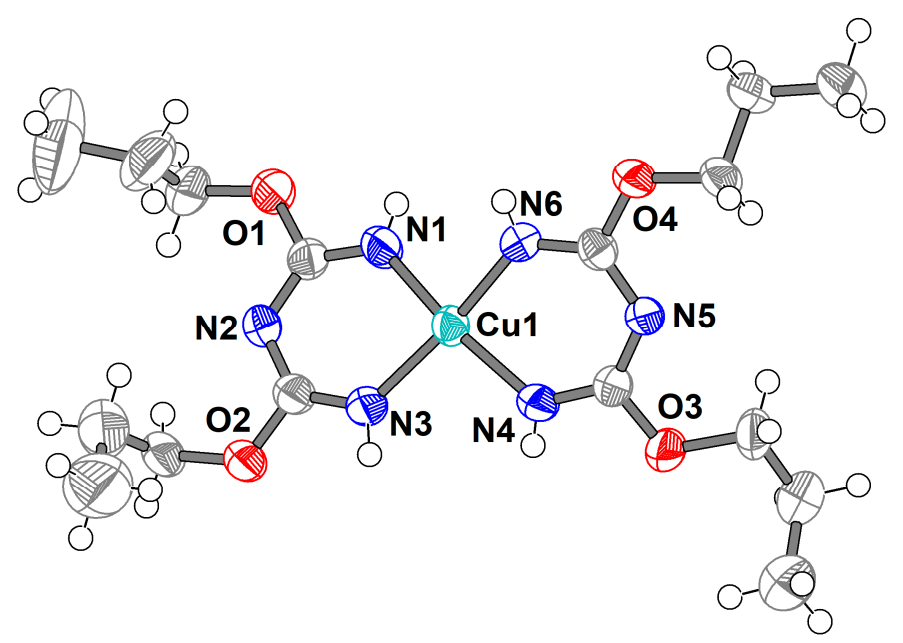

Figure 1. Molecular structure of $\mathbf{3}$ with atom numbering where non-hydrogen atoms are shown as $50 \%$ ellipsoids. 


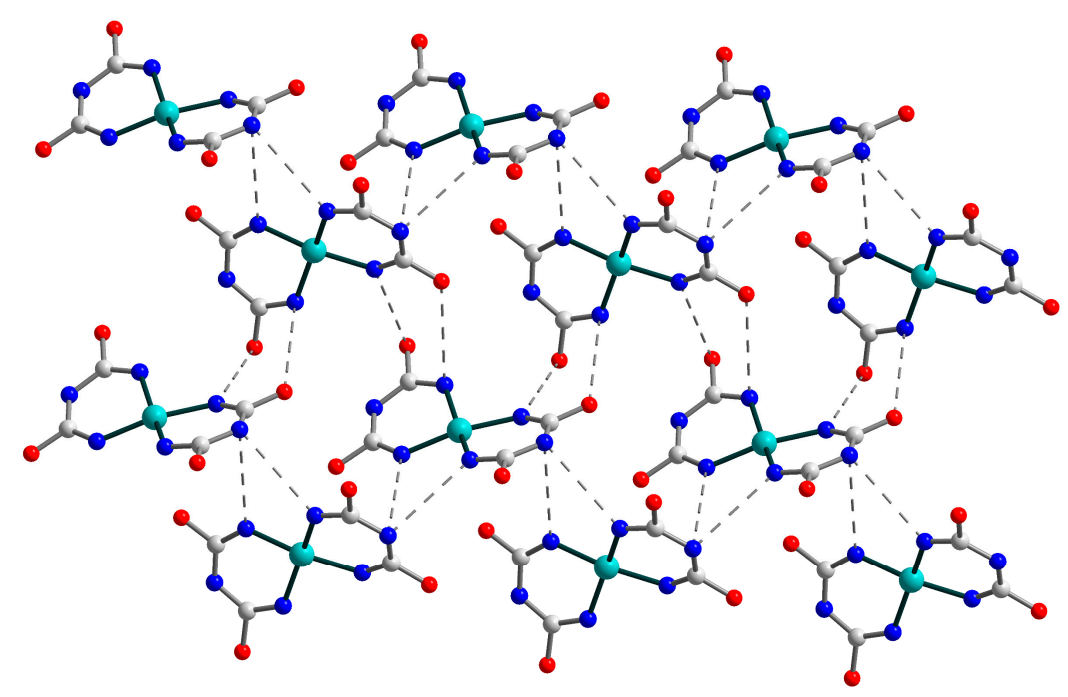

Figure 2. The fragment of the supramolecular layer in 3 viewed down the $a$ axis. $\mathrm{H}$ and $\mathrm{C}$ atoms from the alkyl chains are omitted for clarity. Colour scheme: $\mathrm{Cu}$, cyan; $\mathrm{O}$, red; $\mathrm{N}$, blue; $\mathrm{C}$, grey.

Table 1. Selected geometrical parameters (distances/Å and angles/ ${ }^{\circ}$ ) for 3.

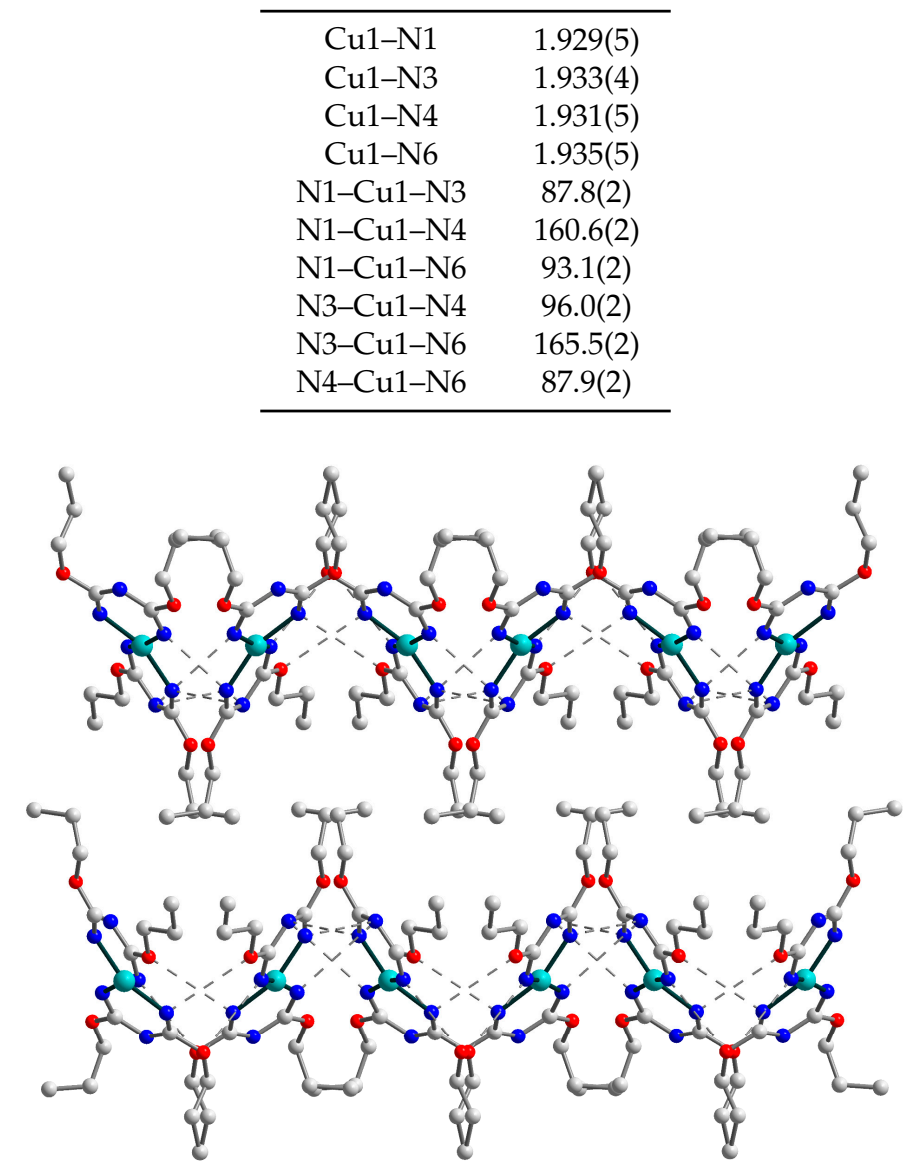

Figure 3. Representation of the packing of supramolecular layers in 3 down the $c$ axis. $\mathrm{H}$ atoms are omitted for clarity. Colour scheme: $\mathrm{Cu}$, cyan; $\mathrm{O}$, red; $\mathrm{N}$, blue; $\mathrm{C}$, grey.

\subsection{Catalytic Oxidation of Cyclohexane with $\mathrm{H}_{2} \mathrm{O}_{2}$}

Cyclohexane is a widely used model substrate for $\mathrm{C}-\mathrm{H}$ oxidation studies due to its suitable bond dissociation energy, easy identification and quantification of reaction products and importance of this process in industry. Thus, we investigated the potential of $\mathbf{1 - 5}$ for the mild oxidation of cyclohexane 
with hydrogen peroxide (Scheme 2). Along with the catalyst, we applied 10 equiv. of pyridine promoter, which is known to enhance the activity of transition metal catalysts, among them copper complexes $[6,38,39]$.

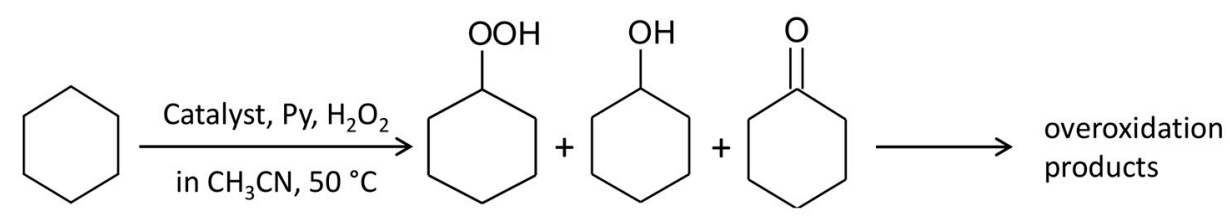

Scheme 2. Main model reaction: oxidation of cyclohexane with $\mathrm{H}_{2} \mathrm{O}_{2}$.

Accumulations of oxygenates (cyclohexanol and cyclohexanone) with time in the cyclohexane oxidation using 1 and 2.5 eq. of $\mathrm{H}_{2} \mathrm{O}_{2}$, catalysed by $\mathbf{1}-\mathbf{5}(0.5 \mathrm{~mol} \%)$, in the presence of pyridine ( $5 \mathrm{~mol} \%$ ) are depicted in Figure 4 . The curves for complexes 1, 2 and 5 exhibit linear dependences at the initial period (Figure 4a). These complexes are least-active, showing equal initial reaction rates $W_{0}$ of $1.8 \times 10^{-7} \mathrm{M} \mathrm{s}^{-1}$ (for 2.5 eq. of $\mathrm{H}_{2} \mathrm{O}_{2}$ ). After $30 \mathrm{~min}$, the reaction rates slightly increase until $1.2 \times$ $10^{-6} \mathrm{M} \mathrm{s}^{-1}$ at $1 \mathrm{~h}$ (for 5, Figure 4a). After this period, all the accumulations undergo sharp accelerations, reaching a plateau after $2 \mathrm{~h}$ (Figure S5). Complex 3 shows the higher $W_{0}$ of $1.7 \times 10^{-6} \mathrm{M} \mathrm{s}^{-1}$ (for $2.5 \mathrm{eq}$. of $\mathrm{H}_{2} \mathrm{O}_{2}$ ). In contrast to 1,2 and 5 , complex 3 exhibits a rather short lag period of $20 \mathrm{~min}$, then reaching the reaction rate of ca. $1 \times 10^{-5} \mathrm{M} \mathrm{s}^{-1}$ at $30 \mathrm{~min}$ time (Figure $4 \mathrm{a}$ ).

The catalytic behaviour of complex 4 was found to be dependent on the time between dissolution of the complex and initiation of the reaction (addition of $\mathrm{H}_{2} \mathrm{O}_{2}$ ). With this time minimized, the accumulation curve is linear in the 20-min period $\left(W_{0}=1.1 \times 10^{-5} \mathrm{M} \mathrm{s}^{-1}\right)$, then showing a gradual decay of the reaction rate with the maximum concentration of oxygenates of $0.021 \mathrm{M}$ which corresponds to the yield of $10.4 \%$ based on cyclohexane (Figure 4a). When complex 4 was kept for 2 min in acetonitrile (at $50{ }^{\circ} \mathrm{C}$ ) prior to the addition of the oxidant, the accumulation curve appeared to be of non-linear character (Figure 4a) with the initial reaction rate $\left(W_{0}=9.9 \times 10^{-6} \mathrm{M} \mathrm{s}^{-1}\right)$ very close to that for the catalytic system without pre-treatment of the complex 4 in acetonitrile.

For comparative purpose, the catalytic properties of copper nitrate were tested using similar conditions with $0.5 \mathrm{~mol} \%$ loading of $\mathrm{Cu}\left(\mathrm{NO}_{3}\right)_{2}$. The choice of copper nitrate was governed due to its solubility in acetonitrile and stability in solution, while the commonly-used copper chloride is known to have complex behaviour, forming polynuclear Cl-bridged species in solution [40] (the same observation can be made for iron chloride also, basing on its non-linear $W_{0} \mathrm{vs}$. [ $\left.\mathrm{FeCl}_{3}\right]_{0}$ dependence) [41]. The accumulation of the reaction products for $\mathrm{Cu}\left(\mathrm{NO}_{3}\right)_{2}$ is linear in the first 40 min time with $W_{0}=1.9$ $\times 10^{-6} \mathrm{M} \mathrm{s}^{-1}$, then reaching a plateau (Figure 4a). Hence, the initial reaction rate exhibited by $\mathrm{Cu}\left(\mathrm{NO}_{3}\right)_{2}$ is considerably lower than that for complex 4 , but higher than for all other complexes.

The accumulations for a 2.5 times lower amount of $\mathrm{H}_{2} \mathrm{O}_{2}(0.2 \mathrm{M} ; 1$ eq.) discloses the drastic difference between complexes 3, 4 and 1, 2, 5 (Figure $4 \mathrm{~b}$ ). While the latter show the negligible activity $\left(W_{0}\right.$ from $5 \times 10^{-8}$ to $8.5 \times 10^{-8} \mathrm{M} \mathrm{s}^{-1}$ ) with slow acceleration, becoming notable only after $1 \mathrm{~h}$, catalysts 3 and 4 demonstrate a rapid increase of their reaction rates with the time (Figure $4 \mathrm{~b}$ ).

The dependences of the initial reaction rates on the oxidant concentration for $\mathbf{1 - 5}$ are depicted at Figure 5. The initial rates $W_{0}$ for catalysts $\mathbf{1}, \mathbf{2}$ and $\mathbf{5}$ are only slightly influenced by the $\mathrm{H}_{2} \mathrm{O}_{2}$ excess. However, the higher $\mathrm{H}_{2} \mathrm{O}_{2}$ concentration causes rapid acceleration of the reactions shortly after their beginnings (Figure S6). Under these conditions, all the complexes show similar yields (18.5\% for 4 ) and the highest turnover frequency (moles of product produced per mol of catalyst per a certain period) of $41 \mathrm{~h}^{-1}$ (for 4). The $W_{0}$ vs. $\left[\mathrm{H}_{2} \mathrm{O}_{2}\right]_{0}$ dependences for complexes 3 and 4 (Figure 5, red and purple lines, respectively) are of nearly linear behaviours, with complex 4 exhibiting saturation when $\left[\mathrm{H}_{2} \mathrm{O}_{2}\right]_{0}>$ $0.5 \mathrm{M}$.

For complex 4, a notable lag period is observed only for the lowest studied $\left[\mathrm{H}_{2} \mathrm{O}_{2}\right]_{0}$ of $0.2 \mathrm{M}$ (Figure $4 \mathrm{~b}$ ). The initial reaction rate $W_{0}$ was found to be $5 \times 10^{-7} \mathrm{M} \mathrm{s}^{-1}$, while the reaction rate at the quasi-linear period $W_{\text {lin }}$ is ca. five times higher $\left(2.7 \times 10^{-6} \mathrm{M} \mathrm{s}^{-1}\right)$. Considering the absence of the 
lag period for $\left[\mathrm{H}_{2} \mathrm{O}_{2}\right]_{0}>0.2 \mathrm{M}$ (Figure $4 \mathrm{~b}$, Figures S6 and S7), one may conclude that the observed initial reaction rates when $\left[\mathrm{H}_{2} \mathrm{O}_{2}\right]_{0}>0.2 \mathrm{M}$ correspond to the $W_{\text {lin }}$, but not to $W_{0}$ (i.e., for complex 4 it is not possible to estimate true $W_{0}$ values for $\left[\mathrm{H}_{2} \mathrm{O}_{2}\right]_{0}>0.2 \mathrm{M}$ ). This assumption is in accord with the nearly linear $W_{\text {lin }}$ vs. $\left[\mathrm{H}_{2} \mathrm{O}_{2}\right]_{0}$ dependence in the $0<\left[\mathrm{H}_{2} \mathrm{O}_{2}\right]_{0}<0.5 \mathrm{M}$ region (Figure 5) when using $W_{\text {lin }}$ value for $\left[\mathrm{H}_{2} \mathrm{O}_{2}\right]_{0}=0.2 \mathrm{M}$ point.

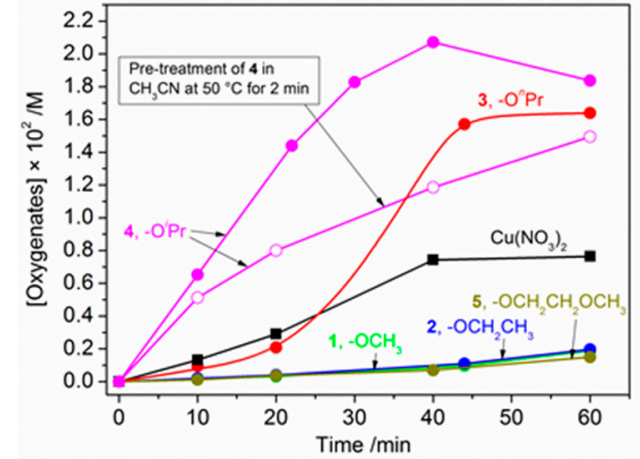

(a)

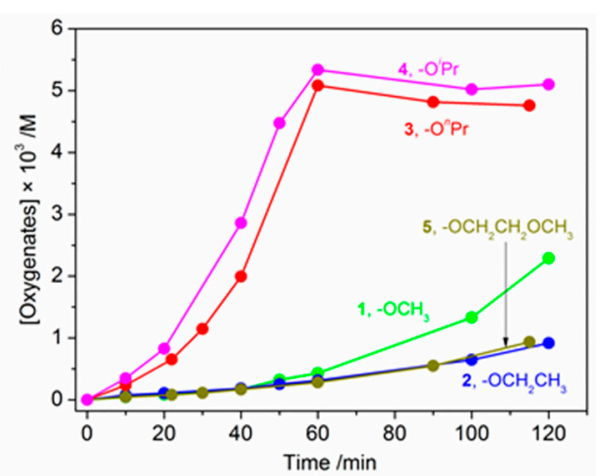

(b)

Figure 4. Accumulations of the reaction products (sum of cyclohexanol and cyclohexanone) in the oxidation of cyclohexane $(0.2 \mathrm{M})$ with $\mathrm{H}_{2} \mathrm{O}_{2}((\mathbf{a})$ : $0.5 \mathrm{M}, 2.5$ equiv.; (b): $0.2 \mathrm{M}, 1$ equiv.) catalysed by 1-5 $\left(1 \times 10^{-3} \mathrm{M}\right)$ and by $\mathrm{Cu}\left(\mathrm{NO}_{3}\right)_{2}\left(1 \times 10^{-3} \mathrm{M}\right)$ in the presence of pyridine $(0.01 \mathrm{M})$ in acetonitrile at $50{ }^{\circ} \mathrm{C}$.

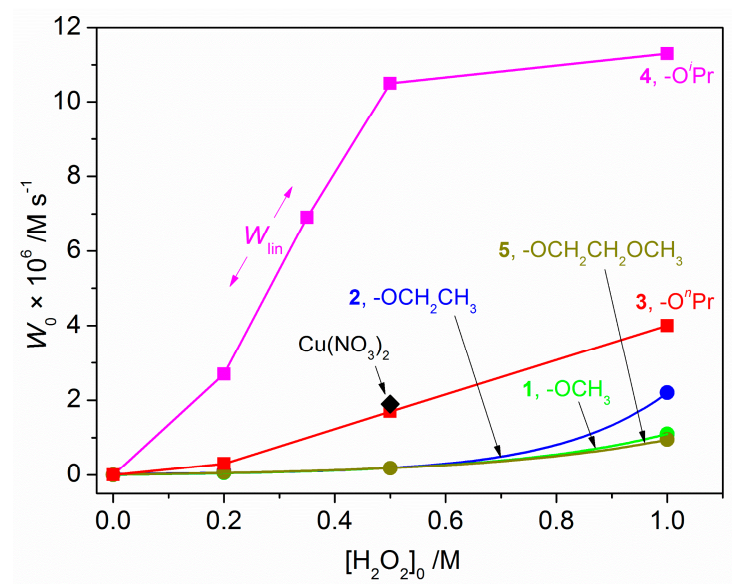

Figure 5. Dependences of the oxidation rates $W_{0}$ on initial concentration of hydrogen peroxide in the oxidation of cyclohexane $(0.2 \mathrm{M})$ with $\mathrm{H}_{2} \mathrm{O}_{2}(50 \%$ aqueous) in the presence of pyridine $(0.01 \mathrm{M})$ in acetonitrile at $50{ }^{\circ} \mathrm{C}$. For complex 4 (purple line), the reaction rate was calculated at the quasi-linear period $\left(W_{\text {lin }}\right)$ because no lag period was observed for $\left[\mathrm{H}_{2} \mathrm{O}_{2}\right]_{0}>0.2 \mathrm{M}$.

The structures of complexes 1-5 differ only by the type of substituents of the triazapentadiene ligands (Scheme 1). Assuming that the rate-limiting step is the reaction of a metal complex with hydrogen peroxide [15,41-46], these substituents appear to be too distanced from the copper centre to sterically hinder this reaction. Considering the catalytic behaviour of $\mathbf{1 - 5}$, one may suppose that the complexes undergo gradual alteration in solution to form species in which catalytic activity is much higher than that of the original complexes. This hypothesis explains the observed acceleration of the reaction rates (Figure 4 and Figures S5-S7) as well as the non-linear increase of the rates with an increase of the oxidant amount (Figure 5). From this point of view, complexes 1, 2 and 5 appear to be more resistant to degradation, while complexes 3 and especially 4 are more prone to that.

We used UV/Vis spectroscopy to monitor the stability of the coordination compounds in the solution. The UV/Vis spectra of 1-5 in acetonitrile solutions are similar, showing a strong absorption band from 287 to $300 \mathrm{~nm}$ and a weak absorption at $492 \mathrm{~nm}$ (Figure 6). The spectra of 1-3 and 5 do not 
undergo changes within $120 \mathrm{~min}$, as evidenced by the intensities of the characteristic absorptions at $492 \mathrm{~nm}$ (Figure $6 \mathrm{~b}$ ). The spectra of $\mathbf{1}$ in the presence of pyridine revealed a slightly lower absorption with no significant changes upon time (Figure $6 \mathrm{~b}$ ). In contrast, the spectra of 4 is evidence for its gradual alteration and degradation in solution (Figure 7a).

The UV/Vis spectra of complex $4\left(1 \times 10^{-3} \mathrm{M}\right)$ in acetonitrile as a function of time are depicted in Figure 7a. After a short lag period, the peak at $492 \mathrm{~nm}$ disappears, while two other absorptions at 428 and $695 \mathrm{~nm}$ become visible (Figure 7a). The intensities of these two bands undergo rapid growth showing maximum at $60 \mathrm{~min}$ time, then decreasing until the background level after $4 \mathrm{~h}$ time. Visually, these changes correspond to the change of the solution colour from red to green $\left(4^{\text {red }} \rightarrow 4^{\text {green }}\right)$ and then to the colourless one with a cloudy precipitate. We were interested in the study of if and how these changes depend on complex 4's concentration and other conditions.

The increase of the intensity of the $428 \mathrm{~nm}$ band is quasi-linear in the ca. 30-50 min range, allowing to calculate its increase rate $W_{428}\left(4.7 \times 10^{-3} \mathrm{~A} \mathrm{~min}^{-1}\right.$ for $\left.[4]_{0}=1 \times 10^{-3} \mathrm{M}\right)$. When the twice lower concentration of complex 4 was used $\left(5 \times 10^{-4} \mathrm{M}\right)$, the $W_{428}$ value was found to be $2.2 \times 10^{-3} \mathrm{~A} \mathrm{~min}^{-1}$. The $W_{428}$ vs. [4] $]_{0}$ data show the dependence which can be approximately treated as a linear one (Figure $7 \mathrm{~b}$, inset). The presence of pyridine affects the maximum intensity of the $428 \mathrm{~nm}$ absorption (Figure $7 \mathrm{~b})$, while the $W_{428}$ rate remains unchanged $\left(3.3 \times 10^{-3} \mathrm{~A} \mathrm{~min}^{-1}\right.$ for $[4]_{0}=1 \times 10^{-3} \mathrm{M}$ and $[\mathrm{Py}]_{0}$ $=0.01 \mathrm{M})$.

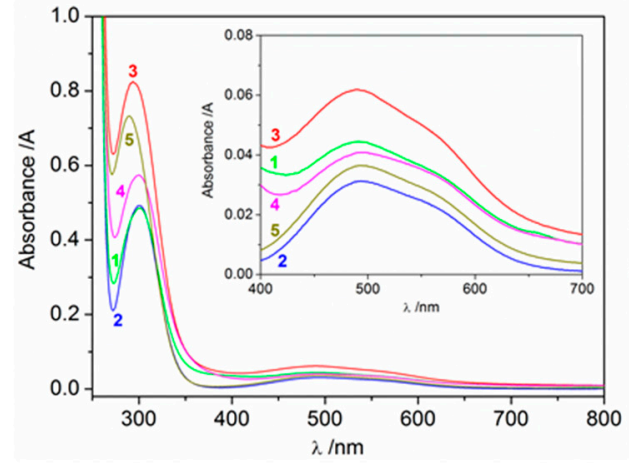

(a)

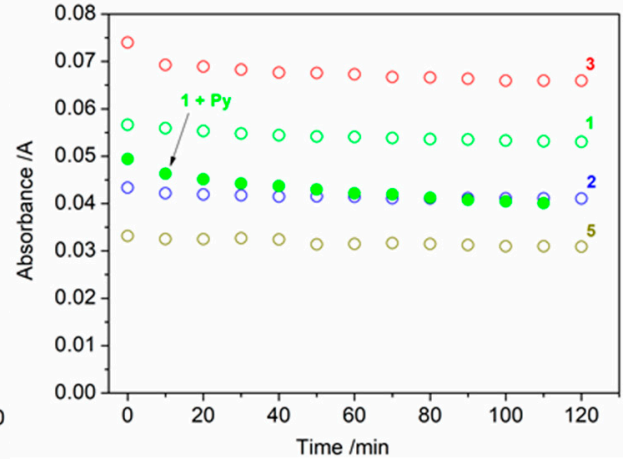

(b)

Figure 6. (a) UV/Vis spectra of 1-5 in acetonitrile $\left(1 \times 10^{-3} \mathrm{M}\right)$ at room temperature. (b) Changes in absorbance at $492 \mathrm{~nm}$ for 1-3 and 5. The dependences for complex $\mathbf{1}$ were measured in the absence (empty circles) and in the presence (solid circles) of pyridine $(0.01 \mathrm{M})$.

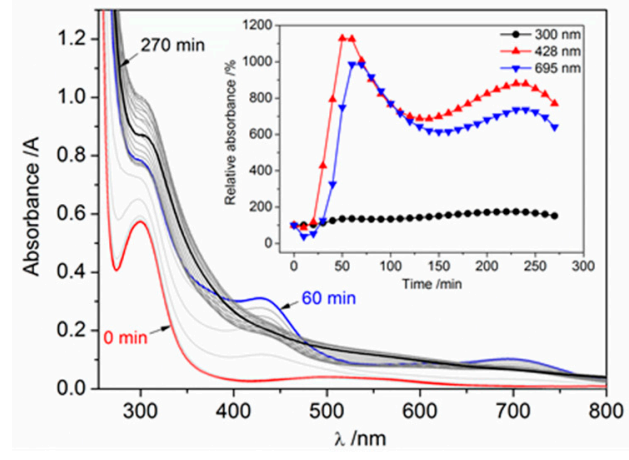

(a)

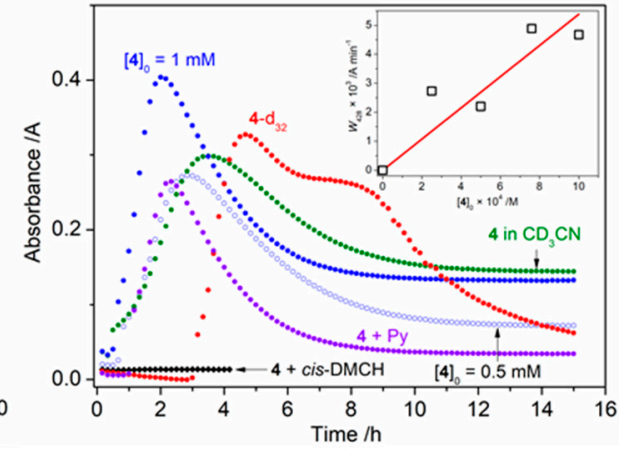

(b)

Figure 7. (a) UV/Vis spectra of 4 in acetonitrile $\left(1 \times 10^{-3} \mathrm{M}\right)$ in the $4 \mathrm{~mL}$ cells along the time. The inset shows changes in the absorbance at 300, 428 and $695 \mathrm{~nm}$ with time. (b) Absorbance at $428 \mathrm{~nm}$ as a function of time for $4\left(1 \times 10^{-3} \mathrm{M}\right.$, unless states otherwise $)$ in the $1.5 \mathrm{~mL}$ cells in normal $\mathrm{CH}_{3} \mathrm{CN}$, 4 in $\mathrm{CH}_{3} \mathrm{CN}$ in the presence of pyridine $(0.01 \mathrm{M}), 4$ in $\mathrm{CD}_{3} \mathrm{CN}$, deuterated $4-\mathrm{d}_{32}$ in $\mathrm{CH}_{3} \mathrm{CN}$, and 4 in $\mathrm{CH}_{3} \mathrm{CN}$ in the presence of cis-1,2-dimethylcyclohexane. The inset shows the dependence of $428 \mathrm{~nm}$ absorbance increase rate $\left(W_{428}\right)$ on $[4]_{0}$. 
The use of deuterated acetonitrile leads to a lower $W_{428}$ rate of $1.9 \times 10^{-3} \mathrm{~A} \mathrm{~min}^{-1}$ and delay of the $428 \mathrm{~nm}$ maximum appearance (Figure $7 \mathrm{~b}$ ). The influence of acetonitrile is clearly seen on the plots of products accumulations in the course of cyclohexane oxidation performed in $\mathrm{CH}_{3} \mathrm{CN}$ and $\mathrm{CD}_{3} \mathrm{CN}$ (Figure 8). While the reaction performed in normal acetonitrile shows acceleration with $W_{0}=$ $5.5 \times 10^{-7} \mathrm{M} \mathrm{s}^{-1}$, the reaction in deuterated acetonitrile shows the constant reaction rate $W=2.2 \times$ $10^{-7} \mathrm{M} \mathrm{s}^{-1}$.

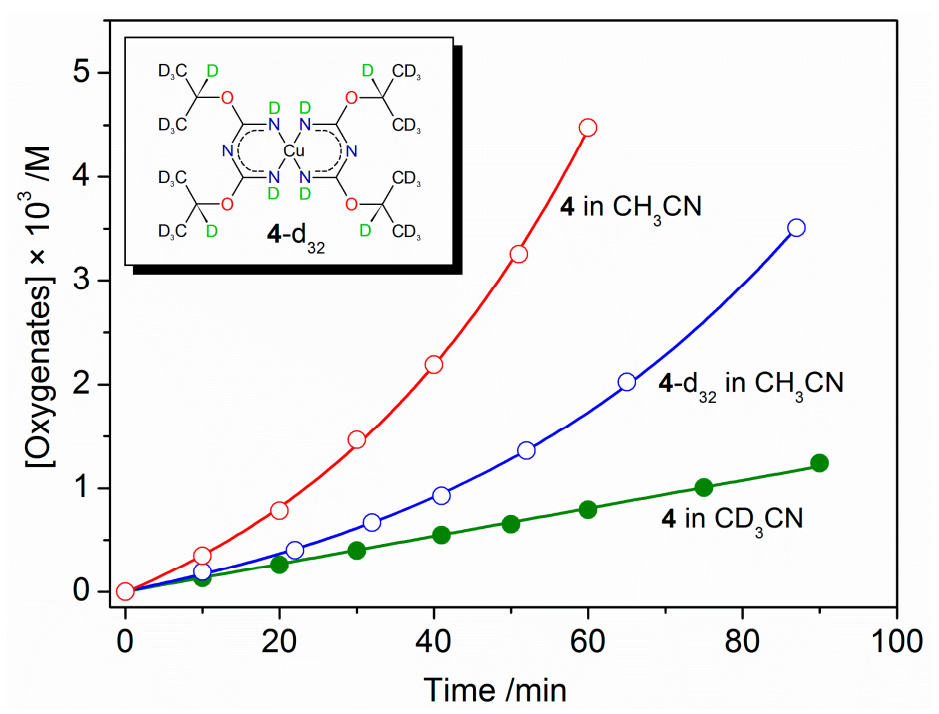

Figure 8. Accumulations of the main reaction products (cyclohexanol and cyclohexanone) with time in the oxidation of cyclohexane $(0.2 \mathrm{M})$ catalysed by $4\left(1 \times 10^{-3} \mathrm{M}\right.$, red blank circles $)$ or $4-\mathrm{d}_{32}\left(1 \times 10^{-3} \mathrm{M}\right.$, green blank circles) in the presence of pyridine $(0.01 \mathrm{M})$ in $\mathrm{CH}_{3} \mathrm{CN}$ (blank circles) or $\mathrm{CD}_{3} \mathrm{CN}$ (solid circles) at $50{ }^{\circ} \mathrm{C}$. Solid lines are exponential or linear fits.

As can be seen, the solution behaviour of complex 4 differs a lot from those for the other complexes. Looking at the structures of all the compounds, one may see the principal feature of complex 4: Each of the triazapentadiene ligands in 4 contain two tertiary $\mathrm{C}-\mathrm{H}$ bonds (Scheme 1, Figure 1 and Figures S1-S4). Since tertiary C-H bonds are typically more active than secondary and primary ones, we assigned the alteration of the structure of 4 in the solution to the activation of this bond with the formation (and consequent degradation) of new species. Considering that complexes 1-5 are known to catalyse aerobic oxidation of alcohols [23], oxidation of the $\mathrm{C}-\mathrm{H}$ bond with dioxygen could be a probable explanation. To confirm such an assumption, we first studied the UV/Vis kinetics of complex $4\left(1 \times 10^{-3} \mathrm{M}\right)$ in acetonitrile in the presence of a large excess $(0.27 \mathrm{M})$ of cis-1,2-dimethylcyclohexane (cis-DMCH). This substrate has easily-oxidizing tertiary $\mathrm{C}-\mathrm{H}$ bonds [47] and in this way can act as a quencher of the reactive $\mathrm{C}-\mathrm{H}$-attacking species. As expected, no changes in the 428 (Figure $7 \mathrm{~b}$ ) and $695 \mathrm{~nm}$ absorptions occurred, only the $287 \mathrm{~nm}$ one showing a slight increase after $4 \mathrm{~h}$. No cis-DMCH oxidation products were detected due to potentially low activity of such catalytic system and the presence of traces of the respective tertiary alcohols in the substrate. Further, when complex 4 was dissolved in degassed acetonitrile $\left([4]_{0}=1 \times 10^{-3} \mathrm{M}\right.$; degassing was performed by freeze-pump-thaw cycling) and stirred under inert atmosphere, no changes in colour were observed during at least $96 \mathrm{~h}$. In case the complexes 1-5 can be oxidized with dioxygen and/or catalyse this process, the oxygen from $\mathrm{O}_{2}$ is expected to appear in the reaction products, first of all water. We attempted to follow this process by dissolving complexes $\mathbf{1}$ and $\mathbf{4}$ (as the most stable and least stable ones) in acetonitrile $\left(2 \times 10^{-3} \mathrm{M}\right)$ and stirring the solutions under the ${ }^{18} \mathrm{O}_{2}$ atmosphere, after the respective degassing. The GCMS analysis of the mixtures, performed after $24 \mathrm{~h}$, revealed the formation of $\mathrm{H}_{2}{ }^{18} \mathrm{O}$ water in the case of complex 1 (Figure S8). In contrast, the solution of complex 4 did not contain detectable amounts of $\mathrm{H}_{2}{ }^{18} \mathrm{O}$ (Figure $\mathrm{S} 8$ ). The absence of ${ }^{18} \mathrm{O}$-labelled water in the case of 4 was surprising; we assume that the labelled species formed could not be detected under the conditions of the experiment. The test 
clearly demonstrates that dioxygen can be activated by the complexes studied (with their possible degradation) and this process can be triggered by the nature of the complex.

An elegant way to enhance the robustness of the catalyst is to protect its oxidation-sensitive $\mathrm{C}-\mathrm{H}$ bonds by their deuteration [48]. The use of a fully deuterated 2-propanol as a solvent enabled the synthesis of the $4-\mathrm{d}_{32}$ complex, containing deuterated ${ }^{i} \mathrm{Pr}-\mathrm{d}_{7}$ moieties including the tertiary $\mathrm{C}-\mathrm{D}$ bonds (Figure 8 , inset). The UV/Vis kinetics of $428 \mathrm{~nm}$ absorption of $4-\mathrm{d}_{32}$ in acetonitrile is depicted in Figure $7 \mathrm{~b}$. The presence of a $3 \mathrm{~h}$ lag period was accounted for $4-\mathrm{d}_{32}$, after which the spectra similar to that for 4 appears. The $W_{428}$ rate was found to be $4.2 \times 10^{-3} \mathrm{~A} \mathrm{~min}^{-1}$. This value is also very close to that for normal complex $4\left(4.7 \times 10^{-3} \mathrm{~A} \mathrm{~min}^{-1}\right)$. A considerable lag period allows recrystallization of $4-d_{32}$ from acetonitrile to produce crystals with unit cell parameters (determined by the single crystal X-ray diffraction) equal to those for 4 , confirming the retention of its integrity.

The accumulation of products (cyclohexanol and cyclohexanone) in the course of cyclohexane oxidation catalysed by $4-\mathrm{d}_{32}$ is depicted in Figure 8 . The reaction shows an acceleration with the initial reaction rate $W_{0}\left(2.5 \times 10^{-7} \mathrm{M} \mathrm{s}^{-1}\right)$ very close to that for the $4-\mathrm{CD}_{3} \mathrm{CN}$ system $\left(2.2 \times 10^{-7} \mathrm{M} \mathrm{s}^{-1}\right)$. However, the acceleration rate exhibited by $4-\mathrm{d}_{32}$ is much lower than that for 4 , as expected for the higher resistance of $4-\mathrm{d}_{32}$ towards oxidation.

Cyclohexyl hydroperoxide, $\mathrm{CyOOH}$, was detected as a main reaction product of the cyclohexane oxidation using catalysts 1-5 (Figure 9). The formation of large amounts of $\mathrm{CyOOH}$ is a sign for a free radical oxidation mechanism, where long-lived alkyl radials react with dioxygen to form alkyl hydroperoxides $[6,24,49,50]$. In the case of $\mathrm{H}_{2} \mathrm{O}_{2}$ oxidant, a free radical mechanism points to an involvement of hydroxyl radicals as attacking species $[6,24,49,50]$. Oxidation of methylcyclohexane $(\mathrm{MeCyH})$ and adamantane catalysed by complexes $\mathbf{1}$ and $\mathbf{4}$ discloses low bond- and regioselectivities as well as the absence of stereoselectivity of these catalytic systems (Table 2). Epimerization of cis-1,2-dimethylcyclohexane (cis-DMCH) stereoconfiguration is a sign for the involvement of long-lived alkyl radicals $[24,49,51]$. These results are consistent with a free-radical mechanism where the $\mathrm{H}$ atom of the $\mathrm{C}-\mathrm{H}$ bond is abstracted by non-selective $\mathrm{HO}$. radicals, catalytically generated from $\mathrm{H}_{2} \mathrm{O}_{2}$ (Table 2) $[6,24,49,50]$. Larger oxygen-centred radicals, such as $t \mathrm{BuO}$. one, result in similar discrimination between secondary and tertiary bonds of adamantane, but much higher bond selectivity in the oxidation of methylcyclohexane due to sterical hindrance of the $\mathrm{R}$ substitutes of the tertiary $\mathrm{R}_{3} \mathrm{C}-\mathrm{H}$ bond (Table 2 ). Higher selectivities are typical for catalytic systems oxidizing $\mathrm{C}-\mathrm{H}$ bonds with high-valent metal-oxo (HVMO) species or metal-peroxide intermediates (Table 2) [14]. For copper, however, such a mechanism is less probable due to the necessity of stabilization of the $\mathrm{Cu}^{\mathrm{III}} \mathrm{HVMO}$ compounds [52-54]. One may note that some $\mathrm{N}_{2}$ - and $\mathrm{N}_{3}$-donor ligands known to stabilize $\mathrm{Cu}^{\mathrm{III}}-\mathrm{O} / \mathrm{Cu}^{\mathrm{II}}-\mathrm{O}$ - species resemble the triazapentadiene ones [55-58].

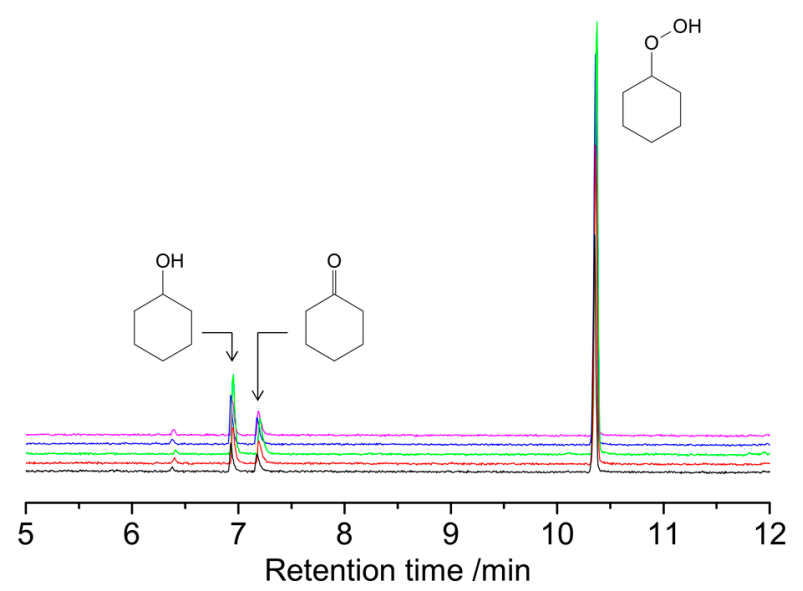

Figure 9. Fragments of the chromatograms of the reaction samples ( $2 \mathrm{~h}$ time) recorded before the addition of $\mathrm{PPh}_{3}$ (Phenomenex ZB-5 column). Small peaks at 6.4 min were assigned to cyclohexene oxide formed as a product of partial decomposition of $\mathrm{CyOOH}$ during the GC analysis. 
The difference between accumulations of the reaction products in normal and deuterated acetonitrile (Figure 8) cannot be explained from the point of view of a free radical mechanism with hydroxyl radicals as attacking species. It is known that the reaction rate of HO- radical with acetonitrile is ca. 100 times lower $\left(k_{4} / k_{3} \sim 0.01\right)$ than with cyclohexane [59-61]:

$$
\begin{gathered}
\text { Catalyst }+\mathrm{H}_{2} \mathrm{O}_{2} \rightarrow \mathrm{HO} \cdot \\
\text { Catalyst }+\mathrm{HO} \cdot \rightarrow \text { degradation products } \\
\mathrm{R}-\mathrm{H}+\mathrm{HO} \cdot \rightarrow \mathrm{R} \cdot+\mathrm{H}_{2} \mathrm{O} \\
\mathrm{CH}_{3} \mathrm{CN}+\mathrm{HO} \cdot \rightarrow \rightarrow \text { products } \\
\mathrm{CD}_{3} \mathrm{CN}+\mathrm{HO} \cdot \rightarrow \rightarrow \text { products }
\end{gathered}
$$

The reaction product appearing from the attack of $\mathrm{HO} \cdot$ to acetonitrile could be acetamide, detected in small amounts by means of GCMS analysis. One may expect that deuterated acetonitrile reacts with $\mathrm{HO}$ - radicals even slowly due to the $\mathrm{D} / \mathrm{H}$ kinetic isotope effect [62]. Hence, if transformation of the complex 4 is caused by the hydroxyl radical attack, such a transformation should be faster in $\mathrm{CD}_{3} \mathrm{CN}$ solvent rather than in $\mathrm{CH}_{3} \mathrm{CN}$ solvent (i.e., $k_{4} / k_{3}>k_{5} / k_{3}$ ). However, this contradicts with the observed accumulations (Figure 8), where complex 4 shows first order dependence in $\mathrm{CD}_{3} \mathrm{CN}$ with the reaction rate considerably lower than that exhibited in $\mathrm{CH}_{3} \mathrm{CN}$ solvent. Finally, since the $\mathbf{4}^{\text {red }} \rightarrow 4^{\text {green }}$ transformation can occur in the absence of $\mathrm{H}_{2} \mathrm{O}_{2}$ (Figure 7), hydroxyl radical attack can be ruled out as a reason for this transformation.

The presence of lag periods in the UV/Vis spectra of 4 suggests an autocatalytic nature of the $4^{\text {red }} \rightarrow 4^{\text {green }}$ reaction, where the $4^{\text {green }}$ intermediate could catalyse further oxidation of the initial complex $4\left(4^{\text {red }}\right)$. An autocatalytic process of this type (involving the $\mathrm{Cu}^{\mathrm{I} / \mathrm{II}}$ cycle) was recently described by Semenov et al. [63], where the reaction product catalysed the electron transfer. The $4^{\text {green }}$ intermediate could be responsible for the $4^{\text {red }} \rightarrow 4^{\text {green }}$ transformation and the acceleration of the reaction rate of cyclohexane oxidation as well (Figures 4 and 8). From this point of view, the different behaviour of 4 in $\mathrm{CH}_{3} \mathrm{CN}$ and $\mathrm{CD}_{3} \mathrm{CN}$ solvents (Figures 7 and 8) can be explained by hampering the autocatalytic process in deuterated solvent, where the latter may act as a ligand.

The typical overoxidation products resulting from cyclohexane oxidation via $\mathrm{HO}$ - radicals are cyclohexanediols and hydroxycyclohexanones [41,64-68]. After notable accumulation of these products, the $\mathrm{C}_{6}$ ring cleavage compounds start to appear. However, in the case of catalysts 1-5, the overoxidation pattern is different from the expected one and, moreover, the amount of 6-hydroxyhexanoic acid is considerably higher than those for cyclohexanediols (Figure 10). Therefore, while the main reaction mechanism is believed to proceed through the hydroxyl radical attack of a $\mathrm{C}-\mathrm{H}$ bond, the pattern of the overoxidation products (Figure 10) evidences for the presence of a minor oxidation mechanism of a different type. Since complexes 1-5 are active catalysts in the aerobic oxidation of alcohols [23], one may suppose that this process is responsible for the oxidation of cyclohexanediols affecting, as a result, the overoxidation pattern.

While cyclohexyl hydroperoxide is a relatively stable compound allowing its observation by means of gas chromatography $[38,64,65,69,70]$, it was interesting to see if the other studied alkanes can also produce detectable alkyl hydroperoxides under the conditions of the experiment. To reach this aim, we compared the chromatograms recorded before and after the addition of solid $\mathrm{PPh}_{3}$ (following the method developed by Shul'pin $[15,50,71]$ ) to the reaction samples (Figures S9-S11). 


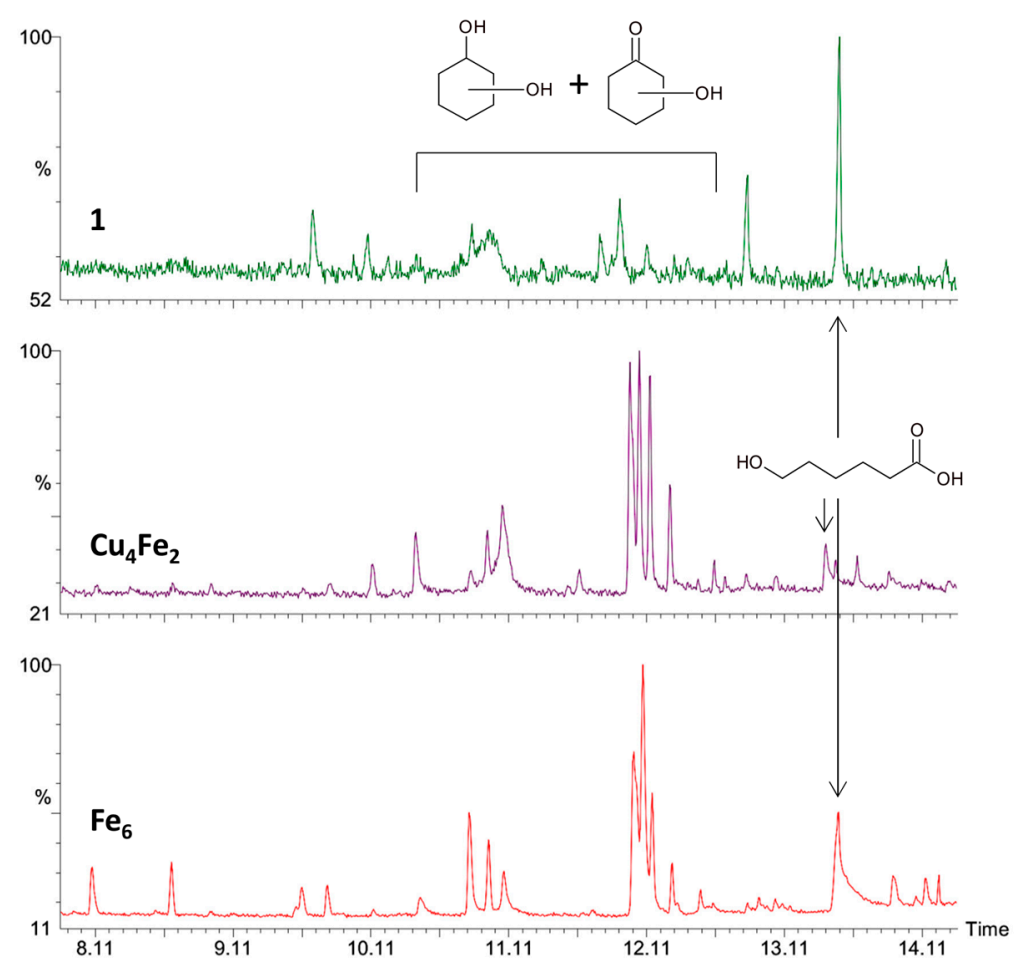

Figure 10. Fragment of the chromatograms showing the overoxidation products in the oxidation of cyclohexane with $\mathrm{H}_{2} \mathrm{O}_{2}$ in acetonitrile catalysed by complex 1 (top), [ $\left.\mathrm{Cu}_{4}{ }_{4} \mathrm{Fe}^{\mathrm{III}}{ }_{2}(\mathrm{OH})(\mathrm{Piv})_{4}(t \mathrm{BuDea})_{4} \mathrm{Cl}\right]$ $\left(\mathbf{C u}_{4} \mathbf{F e}_{2}\right.$, middle) [64] and $\left[\left(\mathrm{PhSiO}_{1.5}\right)_{20}\left(\mathrm{Fe}^{\mathrm{III}} \mathrm{O}_{1.5}\right)_{6}\left(\mathrm{NaO}_{0.5}\right)_{8}(n-\mathrm{BuOH})_{9.6}\left(\mathrm{C}_{7} \mathrm{H}_{8}\right)\right]\left(\mathbf{F e}_{6}\right.$, bottom $)$ [66].

For methylcyclohexane, a group of peaks appearing after the primary alcohol was attributed to methylcyclohexyl hydroperoxides (Figure S9). The mass-spectrum of tertiary peroxide (1-methylhydroperoxide) was found to be consistent with that reported earlier [72]. All hydroperoxide peaks completely disappear after treatment of the sample with $\mathrm{PPh}_{3}$. Oxidation of cis-DMCH affords the expected products (alcohols and ketones), as well as the typical by-products, such as 2,6-octanedione (Figure S10). Two group of peaks were detected, all having identical mass-spectra, with the differences in retention times expected for tertiary trans- and cis-products as well as the products of secondary carbons attack. Earlier, some of us reported similar mass-spectra of the products found in the course of $c i s-\mathrm{DMCH}$ oxidation with the $\mathrm{Cu}_{9} / \mathrm{HNO}_{3} / m$-CPBA catalytic system (where $\mathrm{Cu}_{9}$ is a nonanuclear complex of copper with silsesquioxane and $m$-CPBA is meta-chloroperoxybenzoic acid) in the chromatograms recorded before quenching with $\mathrm{PPh}_{3}$ [73]. Hence, we can tentatively assign the peaks IV and V (Figure S10) to the tertiary trans- and cis-DMCH hydroperoxides which can be reduced to the respective alcohols by using $\mathrm{PPh}_{3}$. In contrast to $\mathrm{MeCyH}$ and cis-DMCH, the analysis of adamantane oxidation products did not afford any peak which could be attributable to an adamantyl hydroperoxide (Figure S11). 
Table 2. Selected bond and stereoselectivity parameters in the oxidation of alkanes ${ }^{a}$.

\begin{tabular}{|c|c|c|c|c|c|c|c|c|}
\hline \multirow{2}{*}{ Catalytic System } & \multicolumn{2}{|c|}{ Cyclohexane } & \multirow{2}{*}{$\begin{array}{l}\text { Methylcyclohexane, } \\
1^{\circ}: 2^{\circ}: 3^{\circ}\end{array}$} & \multicolumn{2}{|c|}{ cis-1,2-Dimethylcyclohexane } & \multirow{2}{*}{$\begin{array}{l}\text { Adamantane } \\
\qquad 3^{\circ}: 2^{\circ}\end{array}$} & \multirow{2}{*}{$\begin{array}{c}\text { Proposed C-H Attacking } \\
\text { Species }\end{array}$} & \multirow{2}{*}{ Ref. } \\
\hline & Yield, $\%^{b}$ & TON $^{c}$ & & cis/trans ratio & $1^{\circ}: 2^{\circ}: 3^{\circ}$ & & & \\
\hline $1 / \mathrm{Py}^{d} / \mathrm{H}_{2} \mathrm{O}_{2}$ & 13 & 27 & $1: 7: 17$ & 1.2 & $1: 7: 34$ & 3:1 & HO. & this work \\
\hline $4 / \mathrm{Py} / \mathrm{H}_{2} \mathrm{O}_{2}$ & 19 & 37 & $1: 8: 18$ & 1.2 & 1:10:44 & 3:1 & $\mathrm{HO}$ & this work \\
\hline$\left[\mathrm{Cu}^{\mathrm{II}}\left(\mathrm{HL}^{1}\right)\left(\mathrm{NO}_{3}\right)(\mathrm{DMF})\right]\left(\mathrm{NO}_{3}\right) \cdot \mathrm{H}_{2} \mathrm{O} / \mathrm{Py} / \mathrm{H}_{2} \mathrm{O}_{2}$ & 22 & 43 & 1:2:16 & - & - & - & $\mathrm{HO}$ & [38] \\
\hline$\left[\mathrm{Cu}^{\mathrm{II}}\left(\mathrm{L}^{2}\right) \mathrm{Cl}_{2}\right] \cdot \mathrm{DMF} / \mathrm{Py} / \mathrm{H}_{2} \mathrm{O}_{2}$ & 21 & 42 & - & 1.3 & 1:7:43 & 3:1 & $\mathrm{HO}$ & [39] \\
\hline$\left[\mathrm{Fe}^{\mathrm{III}}\left(\mathrm{HL}^{1}\right) \mathrm{Cl}_{2}(\mathrm{DMF})\right] \mathrm{Cl} \cdot \mathrm{DMF} / \mathrm{HNO}_{3} / \mathrm{H}_{2} \mathrm{O}_{2}$ & 37 & 900 & $1: 6: 16$ & $\sim 1.0$ & - & - & $\mathrm{HO}$ & [41] \\
\hline$\left[\mathrm{Co}^{\mathrm{III}}{ }_{4} \mathrm{Fe}^{\mathrm{IIII}}{ }_{2} \mathrm{O}\left(\mathrm{L}^{3}\right)_{8}\right] \cdot 4 \mathrm{DMF} \cdot \mathrm{H}_{2} \mathrm{O} / \mathrm{HNO}_{3} / \mathrm{H}_{2} \mathrm{O}_{2}$ & 26 & 3570 & 1:7:20 & - & - & - & $\mathrm{HO}$ & [15] \\
\hline$\left(n-\mathrm{Bu}_{4} \mathrm{~N}\right) \mathrm{V}^{\mathrm{V}} \mathrm{O}_{3 /} / \mathrm{H}_{2} \mathrm{SO}_{4} / \mathrm{H}_{2} \mathrm{O}_{2}$ & - & - & $1: 7: 26$ & $\sim 1.0$ & - & - & HO. & [74] \\
\hline$\left[\mathrm{V}^{\mathrm{V}} \mathrm{O}\left(\mathrm{OCH}_{3}\right)\left(\mathrm{L}^{4}\right)_{2}\right] / \mathrm{PCA}^{e} / \mathrm{H}_{2} \mathrm{O}_{2}$ & 39 & 897 & $1: 5: 17$ & 1.3 & - & - & $\mathrm{HO}$ & [69] \\
\hline$\left[\mathrm{OCu}_{4}{ }^{\mathrm{II}}\left(\mathrm{L}^{5}\right)_{4}(\mathrm{BOH})_{4}\right]\left[\mathrm{BF}_{4}\right]_{2} / \mathrm{CF}_{3} \mathrm{COOH} / \mathrm{H}_{2} \mathrm{O}_{2}$ & 3 & 15 & $1: 5: 14$ & 1.3 & - & - & $\mathrm{HO}$ & [75] \\
\hline$\left[\mathrm{OCu}_{4}{ }_{4}\left(\mathrm{~L}^{5}\right)_{4}(\mathrm{BOH})_{4}\right]\left[\mathrm{BF}_{4}\right]_{2} / \mathrm{TBHP}^{f}$ & 5 & 22 & 1:16:128 & 1.3 & - & - & ${ }^{t} \mathrm{BuO}$ & [75] \\
\hline$\left[\mathrm{Fe}^{\mathrm{III}}\left(\mathrm{L}^{6}\right)(\mathrm{Cl})\right]\left(\mathrm{Et}_{4} \mathrm{~N}\right)_{2} / \mathrm{TBHP}$ & - & - & - & - & - & 3:1 & ${ }^{t} \mathrm{BuO}$ & [76] \\
\hline$\left[\mathrm{Fe}^{\mathrm{III}}\left(\mathrm{L}^{6}\right)(\mathrm{Cl})\right]\left(\mathrm{Et}_{4} \mathrm{~N}\right)_{2} / m-\mathrm{CPBA}^{g}$ & 2 & 5 & - & 30 & & $69: 1$ & $\mathrm{Fe}^{\mathrm{V}}=\mathrm{O}$ & [76] \\
\hline$\left[\mathrm{Mn}^{\mathrm{IV}}{ }_{2}\left(\mathrm{~L}^{7}\right)_{2} \mathrm{O}_{3}\right]\left[\mathrm{PF}_{6}\right]_{2} / \mathrm{HOAc} / \mathrm{H}_{2} \mathrm{O}_{2}$ & 46 & & 1:26:200 & 2.9 & - & - & $\mathrm{Mn}^{\mathrm{V}}=\mathrm{O}$ & [65] \\
\hline$\left[\mathrm{Co}^{\mathrm{II}}\left(\mathrm{L}^{8}\right)\right]\left(\mathrm{NO}_{3}\right)_{2} / m-\mathrm{CPBA}$ & - & - & - & 56 & $0: 1: 35^{h}$ & 21:1 & $\mathrm{Co}^{\mathrm{IV}}=\mathrm{O}$ & [51] \\
\hline$\left[\mathrm{Co}^{\mathrm{II}}\left(\mathrm{L}^{9}\right)\right] / \mathrm{HNO}_{3} / m-\mathrm{CPBA}$ & 8 & 80 & - & 57 & $0: 1: 36$ & - & $\mathrm{Co}^{\mathrm{IV}}=\mathrm{O}$ or $\mathrm{Co}^{\mathrm{III}}-\mathrm{OOC}(\mathrm{O}) \mathrm{Ar}$ & [77] \\
\hline$\left[\mathrm{Co}{ }^{\mathrm{II}}\left(\mathrm{L}^{9}\right)\right] / \mathrm{HNO}_{3 /} \mathrm{H}_{2} \mathrm{O}_{2}$ & - & - & - & 1.1 & $0: 1: 35$ & - & HO. & [77] \\
\hline$\left[\mathrm{Co}^{\mathrm{IIII}}\left(\mathrm{L}^{10}\right)_{3}\right] \cdot \mathrm{DMF} / \mathrm{HNO}_{3} / m-\mathrm{CPBA}$ & - & - & - & 59 & $0: 1: 32$ & 22:1 & $\mathrm{Co}^{\mathrm{IIII}}-\mathrm{OOC}(\mathrm{O}) \mathrm{Ar}$ & [78] \\
\hline$\left[\mathrm{Co}^{\mathrm{IIII}} \mathrm{ZnI}^{\mathrm{II}}\left(\mathrm{L}^{10}\right)_{3} \mathrm{Cl}_{2}\right] \cdot \mathrm{CH}_{3} \mathrm{OH} / \mathrm{HNO}_{3} / m-\mathrm{CPBA}$ & - & - & - & 90 & $0: 1: 38$ & $39: 1$ & 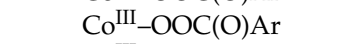 & [79] \\
\hline$\left[\mathrm{Co}^{\mathrm{III}} \mathrm{Cd}^{\mathrm{II}}\left(\mathrm{L}^{10}\right)_{3} \mathrm{Cl}_{2}\right] \cdot 0.5 \mathrm{H}_{2} \mathrm{O} / \mathrm{HNO}_{3} / m-\mathrm{CPBA}$ & - & - & - & 78 & $0: 1: 40$ & 23:1 & $\mathrm{Co}^{\mathrm{III}}-\mathrm{OOC}(\mathrm{O}) \mathrm{Ar}$ & [78] \\
\hline$\left[\mathrm{Ni}^{\mathrm{II}}\left(\mathrm{L}^{11}\right)\left(\mathrm{CH}_{3} \mathrm{CN}\right)_{2}\right]\left(\mathrm{BPh}_{4}\right)_{2} / m-\mathrm{CPBA}$ & 9 & 622 & - & - & - & $13: 1$ & $\mathrm{Ni}{ }^{\mathrm{II}}-\mathrm{O}$ & [80] \\
\hline$\left[\left\{\mathrm{Ni}^{\mathrm{II}}\left(\mathrm{L}^{12}\right)\right\}(\mathrm{OH})_{2}\right] / m-\mathrm{CPBA}$ & 2 & 46 & 1:47:250 & - & - & - & $\mathrm{Ni}^{\mathrm{II}}-\mathrm{OO}(\mathrm{O}) \mathrm{Ar}$ or $\mathrm{Ni}^{\mathrm{II}}-\mathrm{O}$. & [81] \\
\hline$\left[\mathrm{Fe}^{\mathrm{IIII}}\left(\mathrm{L}^{13}\right) \mathrm{Cl}\right] / m-\mathrm{CPBA}$ & 0.3 & 0.9 & - & $>72$ & $0: 1: 58$ & - & $\mathrm{Fe}^{\mathrm{III}}-\mathrm{OOC}(\mathrm{O}) \mathrm{Ar}$ and $\mathrm{Fe}^{\mathrm{IV}}=\mathrm{O}$ & [47] \\
\hline$\left[\mathrm{Fe}^{\mathrm{II}}\left(\mathrm{L}^{14}\right)\left(\mathrm{CF}_{3} \mathrm{SO}_{3}\right)_{2}\right] / \mathrm{H}_{2} \mathrm{O}_{2}$ & 0.7 & 6.5 & - & 28 & - & 30:1 & $\mathrm{Fe}^{\mathrm{V}}=\mathrm{O}$ & [82] \\
\hline
\end{tabular}

${ }^{a}$ Parameters $1^{\circ}: 2^{\circ}: 3^{\circ}$ (for methylcyclohexane and cis-1,2-dimethylcyclohexane) and $3^{\circ}: 2^{\circ}$ (for adamantane) are normalized bond selectivities, corrected for the numbers of respective hydrogen atoms. The cis/trans ratio is the ratio of the tertiary alcohols having methyl groups in cis and trans positions, respectively. ${ }^{b}$ Yield of products (cyclohexanol and cyclohexanone) based on the substrate. ${ }^{c}$ turnover numbers, mols of products per mol of catalyst. ${ }^{d}$ Pyridine. ${ }^{e}$ Pyrazinearboxylic acid. ${ }^{f}$ Tert-butylhydroperoxide. ${ }^{g}$ Meta-chloroperoxybenzoic acid. ${ }^{h}$ Zero value means that the primary alcohol was not detected or its amount is not reported. $\mathrm{HL}^{1}=$ product of condensation of salicylaldehyde and 1 -(2-aminoethyl)piperazine; $\mathrm{HL}^{2}$ $=$ product of condensation of 2-pyridinecarbaldehyde and aminoguanidine; $\mathrm{H}_{2} \mathrm{~L}^{3}=$ salicylidene-2-ethanolamine; $\mathrm{L}^{4}=5$-chloro-8-hydroxyquinoline; $\mathrm{H}_{3} \mathrm{~L}^{5}=$ triethanolamine; $\mathrm{H}_{4} \mathrm{~L}^{6}=$ biuret-amide $\mathrm{N}_{4}$-donor macrocyclic ligand; $\mathrm{L}^{7}=1,4,7$-trimethyl-1,4,7-triazacyclononane; $\mathrm{L}^{8}=$ isoindole-core $\mathrm{N}_{3}$-donor ligand; $\mathrm{L}^{9}=$ phthalocyanine; $\mathrm{L}^{10}=$ product of condensation of $o$-vanillin and methylamine; $\mathrm{L}^{11}=N, N$-Dimethyl- $N, N$-bis(pyrid-2-ylmethyl)ethane-1,2-diamine; $\mathrm{L}^{12}=$ hydrotris(pyrazolyl)borate; $\mathrm{H}_{2} \mathrm{~L}^{13}=$ meso-tetrakis(pentafluorophenyl)porphine; $\mathrm{L}^{14}$ =1-(2-pyridylmethyl)-4,7-dimethyl-1,4,7-triazacyclononane. 


\section{Materials and Methods}

\subsection{Reagents and Materials}

All chemicals were of reagent grade and used as received. Deuterated 2-propanol $\left(99.5 \% d_{8}\right)$ and ${ }^{18} \mathrm{O}$-labelled dioxygen $\left(97.1 \%{ }^{18} \mathrm{O}\right)$ were purchased from CortecNet (Voisins-le-Bretonneux, France). All experiments were carried out in air, unless stated otherwise. UV/Vis spectra were recorded using Lambda 35 spectrometer (PerkinElmer, Waltham, MA, USA) in a 260-800 nm spectral range in the $1 \mathrm{~cm}$ length cells having 1.5 or $4 \mathrm{~mL}$ total volume. Elemental analyses for $\mathrm{C}, \mathrm{H}$ and $\mathrm{N}$ were carried out by the Microanalytical Service of the Instituto Superior Técnico.

\subsection{Crystallography}

The X-ray diffraction data for 3 and 4- $d_{32}$ were collected using a D8 Quest diffractometer (Bruker, Germany) with graphite-monochromated Mo K $\alpha$ radiation. Data were collected using phi and omega scans of $1^{\circ}$ per frame. Cell parameters were retrieved using Bruker SMART software and refined using Bruker SAINT on all the observed reflections. Absorption corrections were applied using SADABS 2016/2 [83]. The structure was solved by direct methods and refined against $F^{2}$ using the program SHELX-2018/3 [84]. The carbon atoms of two of four propyl groups (C3, C4 and C10, C11, C12) were modelled as being disordered over the two positions with site occupancies 0.55(2):0.45(2) and 0.75(2):0.25(2), respectively.

Crystal data for 3: $\mathrm{C}_{16} \mathrm{H}_{32} \mathrm{CuN}_{6} \mathrm{O}_{4}, M=436.01$, monoclinic, $P 2_{1} / c, a=24.916(2) \AA, b=9.3586(9)$ $\AA, c=9.3255(9) \AA, \beta=92.291(3)^{\circ}, V=2172.8(4) \AA^{3}, T=296(2) \mathrm{K}, Z=4,30,396$ reflections collected, of which 4551 were independent, $R_{1}=0.0671$ [based on $I>2 \sigma(I)$ ], $w R_{2}=0.1546$ (based on $F^{2}$ and all data), $\mathrm{GoF}=1.090$. Crystallographic data for the structure reported can be obtained free of charge from the Cambridge Crystallographic Data Centre via www.ccdc.cam.ac.uk/data_request/cif quoting the deposition number CCDC 1903982.

Unit cell parameters for 4- $d_{32}$ (based on the group of 301 reflections): $a=8.232(8) \AA, b=10.513(8)$ $\AA, c=13.674(10) \AA, \alpha=82.36(3)^{\circ}, \beta=74.46(5)^{\circ}, \gamma=82.57(4)^{\circ}, \mathrm{V}=1125(2) \AA^{3}$.

\subsection{Catalytic Oxidation of Alkanes}

To $5 \mu \mathrm{mol}$ of solid catalyst weighed into the reaction flask, $4.1 \mathrm{~mL} \mathrm{CH}_{3} \mathrm{CN}, 50 \mu \mathrm{mol}$ of pyridine (in a form of a stock solution, typically $1.3 \mathrm{M}$ solution in acetonitrile), $0.5 \mathrm{~mL}$ of $\mathrm{CH}_{3} \mathrm{NO}_{2}$ stock solution (internal standard; $1 \mathrm{~mL}$ of $\mathrm{CH}_{3} \mathrm{NO}_{2}$ mixed with $9 \mathrm{~mL}$ of $\mathrm{CH}_{3} \mathrm{CN}$ ), $108 \mu \mathrm{L}(1 \mathrm{mmol}$ ) of cyclohexane and $56-28 \mu \mathrm{L}$ of $50 \%$ aq. $\mathrm{H}_{2} \mathrm{O}_{2}$ were added in this order at $50{ }^{\circ} \mathrm{C}$ under vigorous stirring (CAUTION: the combination of air or molecular oxygen and $\mathrm{H}_{2} \mathrm{O}_{2}$ with organic compounds at elevated temperatures may be explosive!). At the end of the reaction, aliquots (ca. $0.5 \mathrm{~mL}$ ) of the reaction mixture were carefully transferred into a vial containing an excess (ca. $150 \mathrm{mg}$ ) of solid $\mathrm{PPh}_{3}$. A Clarus 500 gas chromatograph (PerkinElmer, Waltham, MA, USA) with a BP-20 capillary column (30 m $\times 0.22 \mathrm{~mm} \times 25 \mu \mathrm{m}$; SGE, Australia) and a Clarus 600 gas chromatograph (PerkinElmer, Waltham, MA, USA), equipped with a Clarus 600 C mass-spectrometer (PerkinElmer, Waltham, MA, USA) (electron impact, $70 \mathrm{eV}$ ), with a ZB-5 capillary columns ( $30 \mathrm{~m} \times 0.25 \mathrm{~mm} \times 25 \mu \mathrm{m}$; Phenomenex, Torrance, CA, USA) and helium carrier gas were used for analyses of the reaction mixtures.

\section{Conclusions}

In this work, we have studied the chemistry and catalytic behaviour of the copper coordination compounds $\left[\mathrm{Cu}\{\mathrm{NH}=\mathrm{C}(\mathrm{OR}) \mathrm{NC}(\mathrm{OR})=\mathrm{NH}\}_{2}\right]$ with a bidentate alkoxy-1,3,5-triazapentadiene ligands having various substituents. Complex 3 was characterized by single crystal $\mathrm{X}$-ray analysis. The coordination compounds show a moderate activity in the cyclohexane oxidation with hydrogen peroxide with the maximum observed reaction rate of $1.1 \times 10^{-5} \mathrm{M} \mathrm{s}^{-1}$, corresponding to the TOF value of $41 \mathrm{~h}^{-1}$. From the selectivity data, kinetic experiments and direct observation of cyclohexyl hydroperoxide, the principal reaction pathway appears to operate via a free radical mechanism 
involving long-lived alkyl radicals. However, there are indications for another minor mechanism of different type, which affects the overoxidation products pattern.

The kinetic data disclosed a complex solution behaviour of all the complexes revealing gradual alteration of their structures in solution. The complex $\mathbf{1}(\mathrm{R}=\mathrm{Me})$ was found to be the most stable compound, while complex $4\left(\mathrm{R}={ }^{i} \mathrm{Pr}\right)$ showed the fastest alteration rate to form an intermediate showing high catalytic activity in cyclohexane oxidation. The lowest stability of complex 4 was associated to the presence of weak tertiary $\mathrm{C}-\mathrm{H}$ bonds in its structure which are aerobically oxidized. Basing on the spectral and kinetic data, an autocatalytic nature of this alteration process was suggested. The use of $\mathrm{CD}_{3} \mathrm{CN}$ instead of $\mathrm{CH}_{3} \mathrm{CN}$ solvent enhanced the stability of 4 presumably by hampering the autooxidation reaction. Protection of complex 4 by deuteration of its ${ }^{i} \operatorname{Pr}$ substituents allowed higher stability of the complex under catalytic conditions. We expect that the results obtained within the present research would improve the understanding of copper-catalysed oxidation processes. Further research will be focused on the characterisation of the intermediate formed from the autooxidation of complex 4 and investigation of the respective reaction mechanism.

Supplementary Materials: The following are available online at http://www.mdpi.com/2304-6740/7/7/82/s1, Figures S1-S4: Ball-and-stick representation of 1,2,4,5 with atom numbering. $\mathrm{H}$ atoms are omitted for clarity; Figure S5: Accumulations of the reaction products (sum of cyclohexanol and cyclohexanone) in the oxidation of cyclohexane $(0.2 \mathrm{M})$ with $\mathrm{H}_{2} \mathrm{O}_{2}(0.5 \mathrm{M})$ catalysed by $1-5\left(1 \times 10^{-3} \mathrm{M}\right)$ and by $\mathrm{Cu}\left(\mathrm{NO}_{3}\right)_{2}\left(1 \times 10^{-3} \mathrm{M}\right)$ in the presence of pyridine $(0.01 \mathrm{M})$ in acetonitrile at $50{ }^{\circ} \mathrm{C}$; Figure S6: Accumulations of the reaction products (sum of cyclohexanol and cyclohexanone) in the oxidation of cyclohexane $(0.2 \mathrm{M})$ with $\mathrm{H}_{2} \mathrm{O}_{2}(\mathrm{M})$ catalysed by 1-5 $\left(1 \times 10^{-3} \mathrm{M}\right)$ in the presence of pyridine $(0.01 \mathrm{M})$ in acetonitrile at $50{ }^{\circ} \mathrm{C}$; Figure S7: Accumulation of the reaction products (sum of cyclohexanol and cyclohexanone) in the oxidation of cyclohexane $(0.2 \mathrm{M})$ with $\mathrm{H}_{2} \mathrm{O}_{2}(0.35 \mathrm{M})$ catalysed by $4\left(1 \times 10^{-3} \mathrm{M}\right)$ in the presence of pyridine $(0.01 \mathrm{M})$ in acetonitrile at $50{ }^{\circ} \mathrm{C}$; Figure S8: Fragments of the chromatograms of the acetonitrile solutions $\left(2 \times 10^{-3} \mathrm{M}\right)$ of $\mathbf{1}$ (bottom) and 4 (top) after stirring for $24 \mathrm{~h}$ under ${ }^{18} \mathrm{O}_{2}$ atmosphere at room temperature, showing the peak at $1.78 \mathrm{~min}$ attributable to water. The inset shows the respective mass-spectra. The presence 19 and $20 \mathrm{~m} / \mathrm{z}$ peaks for the complex 1 account for $\mathrm{H}_{2}{ }^{18} \mathrm{O}$ water. The small peak at 1.74 min corresponds to air; Figure S9: Top: fragments of the chromatograms recorded before and after addition of $\mathrm{PPh}_{3}$ showing the reaction products in the oxidation of methylcyclohexane $(0.2 \mathrm{M})$ with $\mathrm{H}_{2} \mathrm{O}_{2}$ $(0.5 \mathrm{M})$ catalysed by $4\left(1 \times 10^{-3} \mathrm{M}\right)$ in the presence of pyridine $(0.01 \mathrm{M})$ in acetonitrile at $50{ }^{\circ} \mathrm{C}$ after $2 \mathrm{~h}$. Bottom: EI-MS spectra of the peaks attributed to methylcyclohexyl hydroperoxides; Figure S10: Top: fragments of the chromatograms recorded before and after addition of $\mathrm{PPh}_{3}$ showing the reaction products in the oxidation of cis-1,2-dimethylcyclohexane $(0.2 \mathrm{M})$ with $\mathrm{H}_{2} \mathrm{O}_{2}(0.5 \mathrm{M})$ catalysed by $4\left(1 \times 10^{-3} \mathrm{M}\right)$ in the presence of pyridine $(0.01$ $\mathrm{M})$ in acetonitrile at $50{ }^{\circ} \mathrm{C}$ after $2 \mathrm{~h}$. Bottom: EI-MS spectra of the peaks attributed to cis-1,2-dimethylcyclohexyl hydroperoxides; Figure S11: Top: fragment of the chromatograms recorded after addition of $\mathrm{PPh}_{3}$ showing the reaction products in the oxidation of adamantane $(0.2 \mathrm{M})$ with $\mathrm{H}_{2} \mathrm{O}_{2}(0.5 \mathrm{M})$ catalysed by $4\left(1 \times 10^{-3} \mathrm{M}\right)$ in the presence of pyridine $(0.01 \mathrm{M})$ in acetonitrile at $50{ }^{\circ} \mathrm{C}$ after $2 \mathrm{~h}$. Middle and bottom: GCMS $2 \mathrm{D}$ maps of the chromatograms recorded before (middle) and after (bottom) addition of $\mathrm{PPh}_{3}$, showing no difference in the by-products. The peak $12.2 \mathrm{~min}$ is believed to be a residue formed from the degradation of the complex 4 . The CIF and the checkCIF output files of 3 .

Author Contributions: Conceptualization, M.N.K., O.V.N. and D.S.N.; methodology, O.V.N. and D.S.N.; investigation, M.N.K., O.V.N. and D.S.N.; data curation, O.V.N. and D.S.N.; writing—original draft preparation, O.V.N. and D.S.N.; writing-review and editing, M.N.K. and D.S.N.

Funding: This work was supported by the Foundation for Science and Technology (FCT), Portugal (UID/QUI/00100/2019, PTDC/QEQ-QIN/3967/2014, PTDC/QUI-QIN/29778/2017 and contracts IST-ID/086/2018, IST-ID/117/2018 and “Investigador 2013" (IF/01270/2013/CP1163/CT0007).

Conflicts of Interest: The authors declare no conflicts.

\section{References}

1. Gandeepan, P.; Muller, T.; Zell, D.; Cera, G.; Warratz, S.; Ackermann, L. 3d Transition Metals for C-H Activation. Chem. Rev. 2019, 119, 2192-2452. [CrossRef] [PubMed]

2. Karimov, R.R.; Hartwig, J.F. Transition-Metal-Catalyzed Selective Functionalization of C(sp $\left.{ }^{3}\right)-H$ Bonds in Natural Products. Angew. Chem. Int. Ed. 2018, 57, 4234-4241. [CrossRef] [PubMed]

3. Labinger, J.A. Platinum-Catalyzed C-H Functionalization. Chem. Rev. 2017, 117, 8483-8496. [CrossRef] [PubMed] 
4. Cernak, T.; Dykstra, K.D.; Tyagarajan, S.; Vachal, P.; Krska, S.W. The medicinal chemist's toolbox for late stage functionalization of drug-like molecules. Chem. Soc. Rev. 2016, 45, 546-576. [CrossRef] [PubMed]

5. Hartwig, J.F.; Larsen, M.A. Undirected, Homogeneous C-H Bond Functionalization: Challenges and Opportunities. ACS Central Sci. 2016, 2, 281-292. [CrossRef]

6. Nesterov, D.S.; Nesterova, O.V.; Pombeiro, A.J.L. Homo- and heterometallic polynuclear transition metal catalysts for alkane C-H bonds oxidative functionalization: Recent advances. Coord. Chem. Rev. 2018, 355, 199-222. [CrossRef]

7. Crabtree, R.H. The stability of organometallic ligands in oxidation catalysis. J. Organomet. Chem. 2014, 751, 174-180. [CrossRef]

8. Weiner, H.; Finke, R.G. An all-inorganic, polyoxometalate-based catechol dioxygenase that exhibits $>100,000$ catalytic turnovers. J. Am. Chem. Soc. 1999, 121, 9831-9842. [CrossRef]

9. Kim, W.; Yuan, G.; McClure, B.A.; Frei, H. Light Induced Carbon Dioxide Reduction by Water at Binuclear $\mathrm{ZrOCo}^{\mathrm{II}}$ Unit Coupled to Ir Oxide Nanocluster Catalyst. J. Am. Chem. Soc. 2014, 136, 11034-11042. [CrossRef]

10. Geletii, Y.V.; Botar, B.; Koegerler, P.; Hillesheim, D.A.; Musaev, D.G.; Hill, C.L. An all-inorganic, stable, and highly active tetraruthenium homogeneous catalyst for water oxidation. Angew. Chem. Int. Ed. 2008, 47, 3896-3899. [CrossRef]

11. Lv, H.; Song, J.; Geletii, Y.V.; Vickers, J.W.; Sumliner, J.M.; Musaev, D.G.; Koegerler, P.; Zhuk, P.F.; Bacsa, J.; Zhu, G.; et al. An Exceptionally Fast Homogeneous Carbon-Free Cobalt-Based Water Oxidation Catalyst. J. Am. Chem. Soc. 2014, 136, 9268-9271. [CrossRef] [PubMed]

12. Oloo, W.N.; Que, L. Bioinspired Nonheme Iron Catalysts for $\mathrm{C}-\mathrm{H}$ and $\mathrm{C}=\mathrm{C}$ Bond Oxidation: Insights into the Nature of the Metal-Based Oxidants. Acc. Chem. Res. 2015, 48, 2612-2621. [CrossRef] [PubMed]

13. Bryliakov, K.P.; Talsi, E.P. Active sites and mechanisms of bioinspired oxidation with $\mathrm{H}_{2} \mathrm{O}_{2}$, catalyzed by non-heme Fe and related Mn complexes. Coord. Chem. Rev. 2014, 276, 73-96. [CrossRef]

14. Olivo, G.; Cusso, O.; Borrell, M.; Costas, M. Oxidation of alkane and alkene moieties with biologically inspired nonheme iron catalysts and hydrogen peroxide: From free radicals to stereoselective transformations. J. Biol. Inorg. Chem. 2017, 22, 425-452. [CrossRef] [PubMed]

15. Nesterov, D.S.; Chygorin, E.N.; Kokozay, V.N.; Bon, V.V.; Boca, R.; Kozlov, Y.N.; Shul'pina, L.S.; Jezierska, J.; Ozarowski, A.; Pombeiro, A.J.L.; et al. Heterometallic $\mathrm{Co}^{\mathrm{III}}{ }_{4} \mathrm{Fe}{ }_{2}{ }_{2}$ Schiff Base Complex: Structure, Electron Paramagnetic Resonance, and Alkane Oxidation Catalytic Activity. Inorg. Chem. 2012, 51, 9110-9122. [CrossRef] [PubMed]

16. Kopylovich, M.N.; Pombeiro, A.J.L. Coordination chemistry of 1,3,5-triazapentadienes. Coord. Chem. Rev. 2011, 255, 339-355. [CrossRef]

17. Bhunia, S.; Pawar, G.G.; Kumar, S.V.; Jiang, Y.W.; Ma, D.W. Selected Copper-Based Reactions for C-N, C-O, C-S, and C-C Bond Formation. Angew. Chem. Int. Ed. 2017, 56, 16136-16179. [CrossRef]

18. Marchetti, F.; Pettinari, R.; Pettinari, C. Recent advances in acylpyrazolone metal complexes and their potential applications. Coord. Chem. Rev. 2015, 303, 1-31. [CrossRef]

19. Shixallyev, N.Q.; Gurbanov, A.V.; Maharramov, A.M.; Mahmudov, K.T.; Kopylovich, M.N.; Martins, L.; Muzalevskiy, V.M.; Nenajdenko, V.G.; Pombeiro, A.J.L. Halogen-bonded tris(2,4-bis(trichloromethyl)1,3,5-triazapentadienato)-M(III) M = Mn, Fe, Co complexes and their catalytic activity in the peroxidative oxidation of 1-phenylethanol to acetophenone. New J. Chem. 2014, 38, 4807-4815. [CrossRef]

20. Shixaliyev, N.Q.; Maharramov, A.M.; Gurbanov, A.V.; Nenajdenko, V.G.; Muzalevskiy, V.M.; Mahmudov, K.T.; Kopylovich, M.N. Zinc(II)-1,3,5-triazapentadienate complex as effective catalyst in Henry reaction. Catal. Today 2013, 217, 76-79. [CrossRef]

21. Figiel, P.J.; Kopylovich, M.N.; Lasri, J.; da Silva, M.F.C.G.; da Silva, J.J.R.F.; Pombeiro, A.J.L. Solvent-free microwave-assisted peroxidative oxidation of secondary alcohols to the corresponding ketones catalyzed by copper(II) 2,4-alkoxy-1,3,5-triazapentadienato complexes. Chem. Commun. 2010, 46, 2766-2768. [CrossRef] [PubMed]

22. Kopylovich, M.N.; Lasri, J.; da Silva, M.; Pombeiro, A.J.L. Single-pot template transformations of cyanopyridines on a Pd-II centre: Syntheses of ketoimine and 2,4-dipyridyl-1,3,5-triazapentadiene palladium(II) complexes and their catalytic activity for microwave-assisted Suzuki-Miyaura and Heck reactions. Dalton Trans. 2009, 3074-3084. [CrossRef] [PubMed] 
23. Kopylovich, M.N.; Karabach, Y.Y.; da Silva, M.F.C.G.; Figiel, P.J.; Lasri, J.; Pombeiro, A.J.L. Alkoxy1,3,5-triazapentadien(e/ato) Copper(II) Complexes: Template Formation and Applications for the Preparation of Pyrimidines and as Catalysts for Oxidation of Alcohols to Carbonyl Products. Chem. Eur. J. 2012, 18, 899-914. [CrossRef] [PubMed]

24. Shul'pin, G.B. New Trends in Oxidative Functionalization of Carbon-Hydrogen Bonds: A Review. Catalysts 2016, 6, 50. [CrossRef]

25. Wang, F.; Chen, P.H.; Liu, G.S. Copper-Catalyzed Radical Relay for Asymmetric Radical Transformations. Acc. Chem. Res. 2018, 51, 2036-2046. [CrossRef] [PubMed]

26. Trammell, R.; Rajabimoghadam, K.; Garcia-Bosch, I. Copper-Promoted Functionalization of Organic Molecules: From Biologically Relevant $\mathrm{Cu} / \mathrm{O}_{2}$ Model Systems to Organometallic Transformations. Chem. Rev. 2019, 119, 2954-3031. [CrossRef] [PubMed]

27. Bilyachenko, A.N.; Kulakova, A.N.; Levitsky, M.M.; Korlyukov, A.A.; Khrustalev, V.N.; Vologzhanina, A.V.; Titov, A.A.; Dorovatovskii, P.V.; Shul'pina, L.S.; Lamaty, F.; et al. Ionic Complexes of Tetra- and Nonanuclear Cage Copper(II) Phenylsilsesquioxanes: Synthesis and High Activity in Oxidative Catalysis. ChemCatChem 2017, 9, 4437-4447. [CrossRef]

28. Kulakova, A.N.; Korlyukov, A.A.; Zubavichus, Y.V.; Khrustalev, V.N.; Bantreil, X.; Shul'pina, L.S.; Levitsky, M.M.; Ikonnikov, N.S.; Shubina, E.S.; Lamaty, F.; et al. Hexacoppergermsesquioxanes as complexes with N-ligands: Synthesis, structure and catalytic properties. J. Organomet. Chem. 2019, 884, 17-28. [CrossRef]

29. Tran, B.L.; Li, B.J.; Driess, M.; Hartwig, J.F. Copper-Catalyzed Intermolecular Amidation and Imidation of Unactivated Alkanes. J. Am. Chem. Soc. 2014, 136, 2555-2563. [CrossRef]

30. Bakhoda, A.; Jiang, Q.; Badiei, Y.M.; Bertke, J.A.; Cundari, T.R.; Warren, T.H. Copper-Catalyzed C( $\left.\mathrm{sp}^{3}\right)-\mathrm{H}$ Amidation: Sterically Driven Primary and Secondary C-H Site-Selectivity. Angew. Chem. Int. Ed. 2019, 58, 3421-3425. [CrossRef]

31. Teng, F.; Sun, S.; Jiang, Y.; Yu, J.T.; Cheng, J. Copper-catalyzed oxidative C(sp $\left.{ }^{3}\right)-H / N-H$ coupling of sulfoximines and amides with simple alkanes via a radical process. Chem. Commun. 2015, 51, 5902-5905. [CrossRef] [PubMed]

32. Chikkade, P.K.; Kuninobu, Y.; Kanai, M. Copper-catalyzed intermolecular C( $\left.\mathrm{sp}^{3}\right)-\mathrm{H}$ bond functionalization towards the synthesis of tertiary carbamates. Chem. Sci. 2015, 6, 3195-3200. [CrossRef] [PubMed]

33. Zhang, W.; Wang, F.; McCann, S.D.; Wang, D.; Chen, P.; Stahl, S.S.; Liu, G. Enantioselective cyanation of benzylic C-H bonds via copper-catalyzed radical relay. Science 2016, 353, 1014-1018. [CrossRef] [PubMed]

34. Lewis, R.J.; Hutchings, G.J. Recent Advances in the Direct Synthesis of $\mathrm{H}_{2} \mathrm{O}_{2}$. ChemCatChem 2019, 11, $298-308$. [CrossRef]

35. Ranganathan, S.; Sieber, V. Recent Advances in the Direct Synthesis of Hydrogen Peroxide Using Chemical Catalysis-A Review. Catalysts 2018, 8, 22. [CrossRef]

36. Bryliakov, K.P. Catalytic Asymmetric Oxygenations with the Environmentally Benign Oxidants $\mathrm{H}_{2} \mathrm{O}_{2}$ and $\mathrm{O}_{2}$. Chem. Rev. 2017, 117, 11406-11459. [CrossRef]

37. Gamba, I.; Codola, Z.; Lloret-Fillol, J.; Costas, M. Making and breaking of the O-O bond at iron complexes. Coord. Chem. Rev. 2017, 334, 2-24. [CrossRef]

38. Nesterova, O.V.; Nesterov, D.S.; Krogul-Sobczak, A.; da Silva, M.F.C.G.; Pombeiro, A.J.L. Synthesis, crystal structures and catalytic activity of $\mathrm{Cu}(\mathrm{II})$ and $\mathrm{Mn}$ (III) Schiff base complexes: Influence of additives on the oxidation catalysis of cyclohexane and 1-phenylehanol. J. Mol. Catal. A 2017, 426, 506-515. [CrossRef]

39. Buvaylo, E.A.; Kokozay, V.N.; Vassilyeva, O.Y.; Skelton, B.W.; Nesterova, O.V.; Pombeiro, A.J.L. Copper(II) complex of the 2-pyridinecarbaldehyde aminoguanidine Schiff base: Crystal structure and catalytic behaviour in mild oxidation of alkanes. Inorg. Chem. Commun. 2017, 78, 85-90. [CrossRef]

40. Low, S.; Becker, J.; Wurtele, C.; Miska, A.; Kleeberg, C.; Behrens, U.; Walter, O.; Schindler, S. Reactions of Copper(II) Chloride in Solution: Facile Formation of Tetranuclear Copper Clusters and Other Complexes That Are Relevant in Catalytic Redox Processes. Chem. Eur. J. 2013, 19, 5342-5351. [CrossRef]

41. Nesterov, D.S.; Nesterova, O.V.; da Silva, M.F.C.G.; Pombeiro, A.J.L. Catalytic behaviour of a novel Fe(III) Schiff base complex in the mild oxidation of cyclohexane. Catal. Sci. Technol. 2015, 5, 1801-1812. [CrossRef]

42. Rocha, B.G.M.; Kuznetsov, M.L.; Kozlov, Y.N.; Pombeiro, A.J.L.; Shul'pin, G.B. Simple soluble Bi(III) salts as efficient catalysts for the oxidation of alkanes with $\mathrm{H}_{2} \mathrm{O}_{2}$. Catal. Sci. Technol. 2015, 5, 2174-2187. [CrossRef] 
43. Novikov, A.S.; Kuznetsov, M.L.; Pombeiro, A.J.L.; Bokach, N.A.; Shul'pin, G.B. Generation of HO· Radical from Hydrogen Peroxide Catalyzed by Aqua Complexes of the Group III Metals $\left[\mathrm{M}\left(\mathrm{H}_{2} \mathrm{O}\right)_{n}\right]^{3+}(\mathrm{M}=\mathrm{Ga}$, In, Sc, Y, or La): A Theoretical Study. ACS Catal. 2013, 3, 1195-1208. [CrossRef]

44. Kirillova, M.V.; Kuznetsov, M.L.; Kozlov, Y.N.; Shu'pina, L.S.; Kitaygorodskiy, A.; Pombeiro, A.J.L.; Shul'pin, G.B. Participation of Oligovanadates in Alkane Oxidation with $\mathrm{H}_{2} \mathrm{O}_{2}$ Catalyzed by Vanadate Anion in Acidified Acetonitrile: Kinetic and DFT Studies. ACS Catal. 2011, 1, 1511-1520. [CrossRef]

45. Shul'pin, G.B.; Kirillova, M.V.; Kozlov, Y.N.; Shul'pina, L.S.; Kudinov, A.R.; Pombeiro, A.J.L. Decamethylosmocene-catalyzed efficient oxidation of saturated and aromatic hydrocarbons and alcohols with hydrogen peroxide in the presence of pyridine. J. Catal. 2011, 277, 164-172. [CrossRef]

46. Shul'pin, G.B.; Kozlov, Y.N.; Shul'pina, L.S.; Kudinov, A.R.; Mandelli, D. Extremely Efficient Alkane Oxidation by a New Catalytic Reagent $\mathrm{H}_{2} \mathrm{O}_{2} / \mathrm{Os}_{3}(\mathrm{CO})_{12}$ /Pyridine. Inorg. Chem. 2009, 48, 10480-10482. [CrossRef] [PubMed]

47. Nam, W.; Lim, M.H.; Moon, S.K.; Kim, C. Participation of two distinct hydroxylating intermediates in iron(III) porphyrin complex-catalyzed hydroxylation of alkanes. J. Am. Chem. Soc. 2000, 122, 10805-10809. [CrossRef]

48. Codola, Z.; Gamba, I.; Acuna-Pares, F.; Casadevall, C.; Clemancey, M.; Latour, J.-M.; Luis, J.M.; Lloret-Fillol, J.; Costas, M. Design of Iron Coordination Complexes as Highly Active Homogenous Water Oxidation Catalysts by Deuteration of Oxidation-Sensitive Sites. J. Am. Chem. Soc. 2019, 141, 323-333. [CrossRef] [PubMed]

49. Olivo, G.; Lanzalunga, O.; Di Stefano, S. Non-Heme Imine-Based Iron Complexes as Catalysts for Oxidative Processes. Adv. Synth. Catal. 2016, 358, 843-863. [CrossRef]

50. Shul'pin, G.B. Metal-catalyzed hydrocarbon oxygenations in solutions: The dramatic role of additives: A review. J. Mol. Catal. A 2002, 189, 39-66. [CrossRef]

51. Nesterova, O.V.; Kopylovich, M.N.; Nesterov, D.S. Stereoselective oxidation of alkanes with m-CPBA as an oxidant and cobalt complex with isoindole-based ligands as catalysts. RCS Adv. 2016, 6, 93756-93767. [CrossRef]

52. Gunay, A.; Theopold, K.H. C-H Bond Activations by Metal Oxo Compounds. Chem. Rev. 2010, 110, 1060-1081. [CrossRef] [PubMed]

53. Bailey, W.D.; Dhar, D.; Cramblitt, A.C.; Tolman, W.B. Mechanistic Dichotomy in Proton-Coupled Electron-Transfer Reactions of Phenols with a Copper Superoxide Complex. J. Am. Chem. Soc. 2019, 141, 5470-5480. [CrossRef] [PubMed]

54. Dhar, D.; Yee, G.M.; Tolman, W.B. Effects of Charged Ligand Substituents on the Properties of the Formally Copper(III)-Hydroxide $\left([\mathrm{CuOH}]^{2+}\right)$ Unit. Inorg Chem 2018, 57, 9794-9806. [CrossRef] [PubMed]

55. Gagnon, N.; Tolman, W.B. $[\mathrm{CuO}]^{+}$and $[\mathrm{CuOH}]^{2+}$ Complexes: Intermediates in Oxidation Catalysis? Acc. Chem. Res. 2015, 48, 2126-2131. [CrossRef] [PubMed]

56. King, A.E.; Huffman, L.M.; Casitas, A.; Costas, M.; Ribas, X.; Stahl, S.S. Copper-Catalyzed Aerobic Oxidative Functionalization of an Arene C-H Bond: Evidence for an Aryl-Copper(III) Intermediate. J. Am. Chem. Soc. 2010, 132, 12068-12073. [CrossRef]

57. Elwell, C.E.; Gagnon, N.L.; Neisen, B.D.; Dhar, D.; Spaeth, A.D.; Yee, G.M.; Tolman, W.B. Copper-Oxygen Complexes Revisited: Structures, Spectroscopy, and Reactivity. Chem. Rev. 2017, 117, 2059-2107. [CrossRef]

58. McCann, S.D.; Stahl, S.S. Copper-Catalyzed Aerobic Oxidations of Organic Molecules: Pathways for Two-Electron Oxidation with a Four-Electron Oxidant and a One-Electron Redox-Active Catalyst. Acc. Chem. Res. 2015, 48, 1756-1766. [CrossRef]

59. Kozlov, Y.N.; Nizova, G.V.; Shul'pin, G.B. The mechanism of hydrogen peroxide-induced aerobic oxidation of alkanes in catalysis by a vanadium complex and pyrazine-2-carboxylic acid. Russ. J. Phys. Chem. 2001, 75, 770-774.

60. Shul'pin, G.B.; Kozlov, Y.N.; Nizova, G.V.; Suss-Frank, G.; Stanislas, S.; Kitaygorodskiy, A.; Kulikova, V.S. Oxidations by the reagent " $\mathrm{O}_{2}-\mathrm{H}_{2} \mathrm{O}_{2}$-vanadium derivative-pyrazine-2-carboxylic acid". Part 12. Main features, kinetics and mechanism of alkane hydroperoxidation. J. Chem. Soc. Perkin Trans. 2 2001, 1351-1371. [CrossRef]

61. Kozlov, Y.N.; Nizova, G.V.; Shul'pin, G.B. Oxidations by the reagent “ $\mathrm{O}_{2}-\mathrm{H}_{2} \mathrm{O}_{2}$-vanadium derivative-pyrazine-2-carboxylic acid"-Part 14. Competitive oxidation of alkanes and acetonitrile (solvent). J. Mol. Catal. A 2005, 227, 247-253. [CrossRef]

62. Hynes, A.J.; Wine, P.H. Kinetics and Mechanism of the Reaction of Hydroxyl Radicals with Acetonitrile Under Atmospheric Conditions. J. Phys. Chem. 1991, 95, 1232-1240. [CrossRef] 
63. Semenov, S.N.; Belding, L.; Cafferty, B.J.; Mousavi, M.P.S.; Finogenova, A.M.; Cruz, R.S.; Skorb, E.V.; Whitesides, G.M. Autocatalytic Cycles in a Copper-Catalyzed Azide-Alkyne Cycloaddition Reaction. J. Am. Chem. Soc. 2018, 140, 10221-10232. [CrossRef] [PubMed]

64. Nesterova, O.V.; Nesterov, D.S.; Vranovicova, B.; Boca, R.; Pombeiro, A.J.L. Heterometallic $\mathrm{Cu}^{\mathrm{II}} \mathrm{Fe}^{\mathrm{III}}$ and $\mathrm{Cu}^{\mathrm{II}} \mathrm{Mn}^{\mathrm{III}}$ alkoxobridged complexes revealing a rare hexanuclear $\mathrm{M}_{6}(\mu-\mathrm{X})_{7}\left(\mu_{3}-\mathrm{X}\right)_{2}$ molecular core. Dalton Trans. 2018, 47, 10941-10952. [CrossRef]

65. Shul'pin, G.B.; Nesterov, D.S.; Shul'pina, L.S.; Pombeiro, A.J.L. A hydroperoxo-rebound mechanism of alkane oxidation with hydrogen peroxide catalyzed by binuclear manganese(IV) complex in the presence of an acid with involvement of atmospheric dioxygen. Inorg. Chim. Acta 2017, 455, 666-676. [CrossRef]

66. Bilyachenko, A.N.; Levitsky, M.M.; Yalymov, A.I.; Korlyukov, A.A.; Vologzhanina, A.V.; Kozlov, Y.N.; Shul'pina, L.S.; Nesterov, D.S.; Pombeiro, A.J.L.; Lamaty, F.; et al. A heterometallic $\left(\mathrm{Fe}_{6} \mathrm{Na}_{8}\right)$ cage-like silsesquioxane: Synthesis, structure, spin glass behavior and high catalytic activity. RSC Adv. 2016, 6, 48165-48180. [CrossRef]

67. Vinogradov, M.M.; Kozlov, Y.N.; Bilyachenko, A.N.; Nesterov, D.S.; Shul'pina, L.S.; Zubavichus, Y.V.; Pombeiro, A.J.L.; Levitsky, M.M.; Yalymov, A.I.; Shul'pin, G.B. Alkane oxidation with peroxides catalyzed by cage-like copper(II) silsesquioxanes. New J. Chem. 2015, 39, 187-199. [CrossRef]

68. Vinogradov, M.M.; Kozlov, Y.N.; Nesterov, D.S.; Shul'pina, L.S.; Pombeiro, A.J.L.; Shul'pin, G.B. Oxidation of hydrocarbons with $\mathrm{H}_{2} \mathrm{O}_{2} / \mathrm{O}_{2}$ catalyzed by osmium complexes containing p-cymene ligands in acetonitrile. Catal. Sci. Technol. 2014, 4, 3214-3226. [CrossRef]

69. Gryca, I.; Czerwinska, K.; Machura, B.; Chrobok, A.; Shul'pina, L.S.; Kuznetsov, M.L.; Nesterov, D.S.; Kozlov, Y.N.; Pombeiro, A.J.L.; Varyan, I.A.; et al. High Catalytic Activity of Vanadium Complexes in Alkane Oxidations with Hydrogen Peroxide: An Effect of 8-Hydroxyquinoline Derivatives as Noninnocent Ligands. Inorg. Chem. 2018, 57, 1824-1839. [CrossRef]

70. Wierzchowski, P.T.; Zatorski, L.W. Determination of cycle $\mathrm{C}_{6}$ and $\mathrm{C}_{7}$ peroxides and hydroperoxides by gas chromatography. Chromatographia 2000, 51, 83-86. [CrossRef]

71. Bilyachenko, A.N.; Khrustalev, V.N.; Zubavichus, Y.V.; Shul'pina, L.S.; Kulakova, A.N.; Bantreil, X.; Lamaty, F.; Levitsky, M.M.; Gutsul, E.I.; Shubina, E.S.; et al. Heptanuclear $\mathrm{Fe}_{5} \mathrm{Cu}_{2}$-Phenylgermsesquioxane containing 2,2'-Bipyridine: Synthesis, Structure, and Catalytic Activity in Oxidation of C-H Compounds. Inorg. Chem. 2018, 57, 528-534. [CrossRef] [PubMed]

72. Guillois, K.; Mangematin, S.; Tuel, A.; Caps, V. Gold-catalyzed aerobic epoxidation of trans-stilbene in methylcyclohexane. Part II: Identification and quantification of a key reaction intermediate. Catal. Today 2013, 203, 111-115. [CrossRef]

73. Astakhov, G.S.; Bilyachenko, A.N.; Korlyukov, A.A.; Levitsky, M.M.; Shul'pina, L.S.; Bantreil, X.; Lamaty, F.; Vologzhanina, A.V.; Shubina, E.S.; Dorovatovskii, P.V.; et al. High-Cluster $\left(\mathrm{Cu}_{9}\right)$ Cage Silsesquioxanes: Synthesis, Structure, and Catalytic Activity. Inorg. Chem. 2018, 57, 11524-11529. [CrossRef] [PubMed]

74. Kirillova, M.V.; Kuznetsov, M.L.; Romakh, V.B.; Shul'pina, L.S.; Frausto da Silva, J.J.R.; Pombeiro, A.J.L.; Shul'pin, G.B. Mechanism of oxidations with $\mathrm{H}_{2} \mathrm{O}_{2}$ catalyzed by vanadate anion or oxovanadium(V) triethanolaminate (vanadatrane) in combination with pyrazine-2-carboxylic acid (PCA): Kinetic and DFT studies. J. Catal. 2009, 267, 140-157. [CrossRef]

75. Kirillova, M.V.; Kirillov, A.M.; Mandelli, D.; Carvalho, W.A.; Pombeiro, A.J.L.; Shul'pin, G.B. Mild homogeneous oxidation of alkanes and alcohols including glycerol with tert-butyl hydroperoxide catalyzed by a tetracopper(II) complex. J. Catal. 2010, 272, 9-17. [CrossRef]

76. Ghosh, M.; Pattanayak, S.; Dhar, B.B.; Singh, K.K.; Panda, C.; Sen Gupta, S. Selective C-H Bond Oxidation Catalyzed by the Fe-bTAML Complex: Mechanistic Implications. Inorg. Chem. 2017, 56, 10852-10860. [CrossRef] [PubMed]

77. Nesterov, D.S.; Nesterova, O.V.; Kopylovich, M.N.; Pombeiro, A.J.L. Pronounced retention of stereoconfiguration upon $\mathrm{sp}^{3} \mathrm{C}-\mathrm{H}$ bonds hydroxylation of dimethylcyclohexanes and decahydronaphthalenes with m-CPBA oxidant and a Co-phthalocyanine catalyst. Mol. Catal. 2018, 459, 8-15. [CrossRef]

78. Nesterova, O.V.; Kasyanova, K.V.; Makhankova, V.G.; Kokozay, V.N.; Vassilyeva, O.Y.; Skelton, B.W.; Nesterov, D.S.; Pombeiro, A.J.L. Stereospecific $\mathrm{sp}^{3}$ C-H oxidation with $m$-CPBA: A CoIII Schiff base complex as pre-catalyst vs. its $\mathrm{Co}^{\mathrm{III}} \mathrm{Cd}^{\mathrm{II}}$ heterometallic derivative. Appl. Catal. A 2018, 560, 171-184. [CrossRef] 
79. Nesterova, O.V.; Kasyanova, K.V.; Buvaylo, E.A.; Vassilyeva, O.Yu.; Skelton, B.W.; Nesterov, D.S.; Pombeiro, A.J.L. Heterometallic Co ${ }^{\mathrm{III}} \mathrm{Zn}^{\mathrm{II}}$ Schiff Base Catalyst for Mild Hydroxylation of C( $\left.\mathrm{sp}^{3}\right)-\mathrm{H}$ Bonds of Unactivated Alkanes: Evidence for Dual Mechanism Controlled by the Promoter. Catalysts 2019, 9, 209. [CrossRef]

80. Balamurugan, M.; Mayilmurugan, R.; Suresh, E.; Palaniandavar, M. Nickel(II) complexes of tripodal 4N ligands as catalysts for alkane oxidation using $m$-CPBA as oxidant: Ligand stereoelectronic effects on catalysis. Dalton Trans. 2011, 40, 9413-9424. [CrossRef]

81. Hikichi, S.; Hanaue, K.; Fujimura, T.; Okuda, H.; Nakazawa, J.; Ohzu, Y.; Kobayashi, C.; Akita, M. Characterization of nickel(II)-acylperoxo species relevant to catalytic alkane hydroxylation by nickel complex with mCPBA. Dalton Trans. 2013, 42, 3346-3356. [CrossRef]

82. Company, A.; Gomez, L.; Guell, M.; Ribas, X.; Luis, J.M.; Que, L.; Costas, M. Alkane hydroxylation by a nonheme iron catalyst that challenges the heme paradigm for oxygenase action. J. Am. Chem. Soc. 2007, 129, 15766-15777. [CrossRef] [PubMed]

83. Krause, L.; Herbst-Irmer, R.; Sheldrick, G.M.; Stalke, D. Comparison of silver and molybdenum microfocus X-ray sources for single-crystal structure determination. J. Appl. Crystallogr. 2015, 48, 3-10. [CrossRef] [PubMed]

84. Sheldrick, G.M. Crystal structure refinement with SHELXL. Acta Crystallogr. C 2015, 71, 3-8. [CrossRef] [PubMed]

(C) 2019 by the authors. Licensee MDPI, Basel, Switzerland. This article is an open access article distributed under the terms and conditions of the Creative Commons Attribution (CC BY) license (http://creativecommons.org/licenses/by/4.0/). 